\title{
27. EFFECTS OF ALTERATION ON PHYSICAL PROPERTIES OF BASALTS FROM THE PIGAFETTA AND EAST MARIANA BASINS ${ }^{1}$
}

\author{
William H. Busch, ${ }^{2}$ P. R. Castillo, ${ }^{3}$ P. A. Floyd, ${ }^{4}$ and G. Cameron ${ }^{5}$
}

\begin{abstract}
Physical properties of basalts from Ocean Drilling Program Sites 800 and 801 in the Pigafetta Basin and Site 802 in the East Mariana Basin, including porosity, wet-bulk density, grain density, compressional wave velocity, and thermal conductivity, were measured aboard JOIDES Resolution during Leg 129. The ranges for the properties are large, as typified by the velocity, which varies from 3.46 to $6.59 \mathrm{~km} / \mathrm{s}$. Extensively altered basalts immediately above and below a silicified hydrothermal deposit (60-69 m sub-basement depth) at Site 801 display the highest porosity, and lowest bulk density, velocity, and thermal conductivity, whereas the slightly altered rocks from Site 802 and the lowermost part of Site 801 represent the other extreme in physical properties variations. In order to better establish the relationship between physical properties and alteration of the rocks, the compressional wave velocities were compared with results from major and trace elemental analyses and petrographic examination of select samples. For the Leg 129 basalts, velocity displays a generally consistent decrease with increasing $\mathrm{K}_{2} \mathrm{O}, \mathrm{H}_{2} \mathrm{O}+$, loss on ignition, and $\mathrm{Rb}$ contents and the value of $\mathrm{Fe}^{3+} / \mathrm{Fe}_{\mathrm{T}}$ and decreasing concentrations of $\mathrm{SiO}_{2}, \mathrm{FeO}_{\mathrm{T}}, \mathrm{CaO}, \mathrm{MgO}$, and $\mathrm{MnO}$. These trends are consistent with trends documented for the progressive alteration of oceanic crust and indicate that on a laboratory sample scale, basalt alteration is largely responsible for the variation of the physical properties of basalts sampled at Sites 800 , 801 , and 802 .
\end{abstract}

\section{INTRODUCTION}

The good recovery of basement rocks in the Pigafetta Basin at Sites 800 and 801 and in the East Mariana Basin at Site 802 allowed for extensive physical properties measurements of these materials during Ocean Drilling Program (ODP) Leg 129. At Site 801 Middle Jurassic age rocks were recovered, representing the oldest oceanic crust sampled in situ. One of the objectives of this study is to document the variation in physical properties (porosity, bulk density, grain density, compressional wave velocity, and thermal conductivity) of the basalts recovered during Leg 129, highlighting the properties of the Jurassic crust sampled at Site 801 . During determination of the physical properties it was observed that the properties varied widely and that the variation corresponded with the visible indications of alteration of the rocks. The second objective of this study is to better define the relationship between the physical properties and the alteration of the basalts.

\section{STUDY MATERIALS}

Igneous rocks were sampled at all three sites drilled during Leg 129 (Fig. 1). Hole 800A, in the northeastern Pigafetta Basin, was terminated in dolerite sills of Early Cretaceous age (Erba and Covington, this volume; Pringle, this volume), after $46 \mathrm{~m}$ of penetration. The two holes at Site 801 in the central Pigafetta Basin, Holes 801B and 801C, penetrated thin flows and pillow lavas of late Middle Jurassic age (Matsuoka, this volume; Pringle, this volume). The combined total penetration into basalt at Holes $801 \mathrm{~B}$ and $801 \mathrm{C}$ is $133 \mathrm{~m}$. Hole $802 \mathrm{~A}$, located in the central part of the East Mariana Basin, penetrated $51 \mathrm{~m}$ of thin flows and pillow lavas. These lavas are Early Cretaceous in age (Erba and Covington, this volume; Pringle, this volume). Core recovery in the basement-rock sections drilled at Holes $800 \mathrm{~A}, 801 \mathrm{~B}, 801 \mathrm{C}$, and $802 \mathrm{~A}$ was $12 \%, 31 \%, 60 \%$, and $33 \%$, respectively.

\footnotetext{
'Larson, R. L., Lancelot, Y., et al., 1992. Proc. ODP, Sci. Results, 129: College Station, TX (Ocean Drilling Program).

${ }^{2}$ Department of Geology and Geophysics, University of New Orleans, New Orleans, LA 70148, U.S.A.

${ }^{3}$ Scripps Institution of Oceanography, La Jolla, CA 92093-0220, U.S.A

${ }^{4}$ Department of Geology, University of Keele, Keele, Staffordshire, ST5 5BG, United Kinģdom.

44 Ochterloney St., Dartmouth, Nova Scotia, B2Y 1B9, Canada.
}

Three massive alkali dolerite sills, identified on the basis of textural variation and the presence of a sedimentary interlayer, were sampled at Site 800 . The dolerites are slightly miarolitic, largely holocrystalline, and aphyric but with characteristically long $(5-15 \mathrm{~mm})$ pyroxene crystals. The samples are moderately to heavily (20\%-55\%) altered. Low-grade alteration products include pervasive brown and green smectitic clays, hydrated iron oxides, calcite, and pyrite and lesser amounts of chlorite, sericite, and possibly celadonite. Higher grade alteration assemblages, consisting of secondary actinolite and biotite, are also present and indicate a possible protracted emplacement of the sills.

Basement rocks at Site 801 are divided into two sequences separated by a silicified hydrothermal deposit that is at least $2.6 \mathrm{~m}$ thick (recovered thickness). The upper alkalic basalt sequence is approximately $60 \mathrm{~m}$ thick and consists primarily of aphyric basalt and microdolerite lava flows and a few thin dikes; these generally have glassy variolitic margins and holocrystalline interiors. The lower tholeiitic sequence is composed of many thin ( $<4 \mathrm{~m}$ thick) flows, some pillow lavas, and one thick flow, approximately $13.5 \mathrm{~m}$ thick. In its upper part the tholeiitic sequence contains sparsely to moderately plagioclase-olivine ( \pm spinel) phyric basalts, representing the most primitive composition at Site 801 . The lower part of the tholeiitic sequence consists primarily of aphyric basalt. The chemical and isotopic features of the tholeiitic sequence indicate that these rocks are Jurassic analogues of modern Pacific mid-ocean ridge basalts, whereas the overlying alkali basalts are interpreted to represent materials generated off-axis after this segment of Jurassic oceanic crust drifted away from the active ridge (Floyd and Castillo, this volume).

Alteration of the Site 801 basalts ranges from slight $(\approx 10 \%)$ to very high (up to $100 \%$ ). The tholeiites immediately below the hydrothermal deposit (below $531 \mathrm{~m}$ below seafloor, mbsf) are the most extensively altered rocks. However, the lower sequence tholeiites as a whole are generally less altered than the upper sequence alkali basalts (Alt et al., this volume). Low-grade alteration products, such as smectitic clays, calcite, zeolites, chlorite, iron-hydroxides, and talc(?), are widespread in occurrence. Late-stage oxidative-type alteration characterizes the upper part of the alkali basalt sequence and is particularly well developed in the tholeiitic sequence immediately below the hydrothermal deposit. Limited occurrence of biotite in the basalts above the hydrothermal deposit, represents a late-stage higher grade alteration most likely associated with the intrusive units in this part of the sequence. 


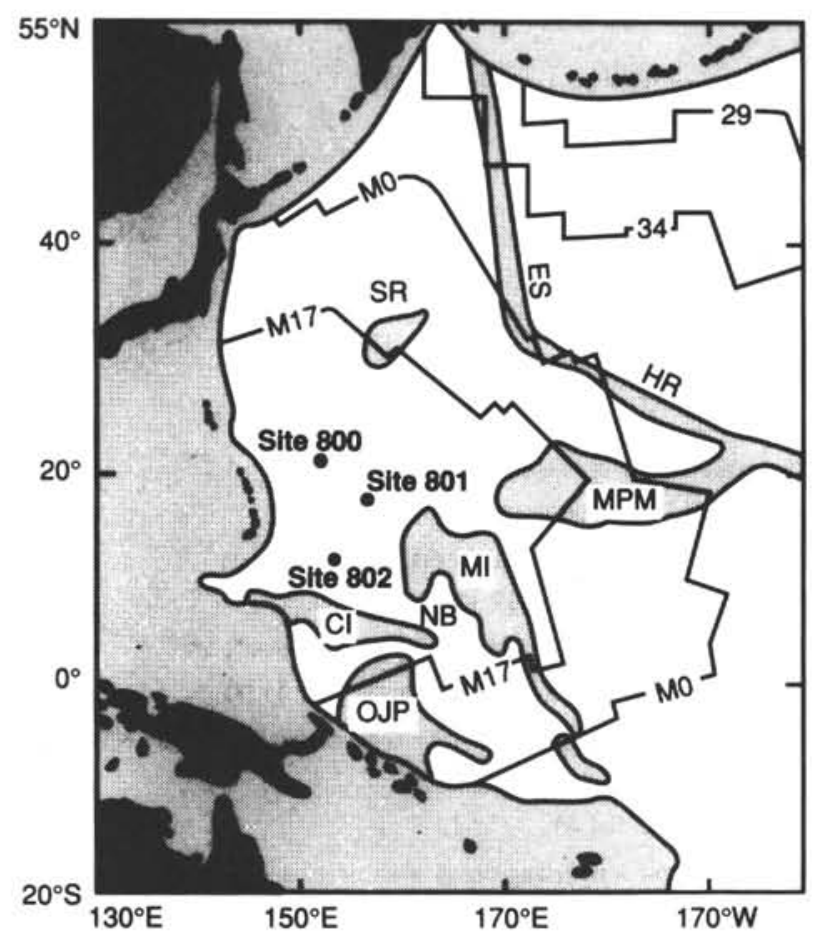

Figure 1. Location of Sites 800, 801, and 802 in the western Pacific (Lancelot, Larson, et al., 1990). Jagged contours represent magnetic lineations and unshaded areas represent normal Pacific oceanic crust. Shaded areas represent volcanic edifices with thickened crustal sections, as well as the younger areas beyond the Pacific subduction zones.

Basalts sampled at Site 802 consist of a large number (at least 17) thin flows and pillow lavas. The rocks are primarily aphyric and sparsely plagioclase-clinopyroxene-olivine microphyric, hypocrystalline, tholeiitic basalts that exhibit glassy spherulitic rims and quench-textured flow interiors. The basalts are only slightly altered. Alteration is dominated by low-grade assemblages of smectitic clays, calcite, and pyrite that formed under mildly alkaline, reducing conditions. A late oxidative alteration phase is not evident.

\section{METHODS}

A total of 48 basalt and dolerite samples were analyzed for physical properties during Leg 129. Samples were typically selected from homogenous materials, avoiding, as much as possible, veins and veinlets, fractures, and intervals disturbed by coring. Detailed descriptions of the analytical techniques used in the determination of the physical properties of the Leg 129 igneous rocks are provided in Lancelot, Larson, et al. (1990). The following is a brief summary of the procedures.

Bulk properties (porosity, wet-bulk density, and average grain density) and compressional wave velocity were determined for samples with a $2.1-\times 2.1-\mathrm{cm}$ cross section cut from split-core sections using a double-bladed diamond saw. The bulk properties were calculated from measurements of wet and dry weights and dry volume. Before determination of the wet weight and velocity, the samples were placed in filtered seawater for at least $2 \mathrm{hr}$ to resaturate the rocks. Dry measurements of the samples were made after the rocks were dried at $105^{\circ} \mathrm{C}$ for $24 \mathrm{hr}$ and allowed to cool in a desiccator. Weight measurements were made with a pair of motioncompensating electronic balances and were determined to a accuracy of $\pm 0.01 \mathrm{~g}$, with a repeatability of $\pm 0.04 \mathrm{~g}$. Volume measurements were made with a helium-displacement pycnometer and were typically repeatable to $\pm 0.05 \mathrm{~cm}^{3}$. A salt correction was applied to porosity, grain density, dry-bulk density, and water content computations as per Hamilton (1971). The correction was not applied to the determination of wet-bulk density. Based on the precision of the weight and volume measurements, the precision of the derived properties is $\pm 0.016 \mathrm{~g} / \mathrm{cm}^{3}$ for grain density, $\pm 0.024 \mathrm{~g} / \mathrm{cm}^{3}$ for wet-bulk density, $\pm 0.030 \mathrm{~g} / \mathrm{cm}^{3}$ for dry-bulk density, $\pm 0.62 \%$ for porosity, and $\pm 0.24 \%$ for water content. Wet-bulk density was also determined using the gammaray attenuation porosity evaluator (GRAPE) 2-min count technique (Boyce, 1976). The average difference between the wet-bulk density and gravimetrically determined wet-bulk density, $0.013 \mathrm{~g} / \mathrm{cm}^{3}$, was determined to be not statistically significant.

Compressional wave velocity was determined by the pulse-transmission method using ultrasonic piezometric transducers and detectors in a screw-press Hamilton Frame, described by Boyce (1976). Measurements were made at atmospheric pressure and temperature with an estimated accuracy of $\pm 1 \%$. Compressional wave velocity was determined for both vertical (parallel to the core axis) and horizontal (perpendicular to the core axis) propagation directions. Velocity anisotropy was calculated from the vertical and horizontal velocity values following the relationship of Carlson and Christensen (1979), where anisotropy is given as the ratio of the velocity difference to the mean velocity, expressed as a percentage.

Thermal conductivity was measured for polished split-core segments using the half-space technique (Vacquier, 1985). In this method samples are placed on top of a needle probe embedded along the surface of a slab of low-conductivity material and immersed in a water bath. Measurements were made after the samples equilibrated to a temperature drift less than $0.04^{\circ} \mathrm{C} / \mathrm{min}$. Conductivity measurements were based on the time interval for which the temperature rise varied logarithmically with time, 60 to $240 \mathrm{~s}$ after the needle-probe heater was turned on. All data were corrected for in-situ pressure and temperature (Ratcliffe, 1960), and the estimated error is about $5 \%-10 \%$.

In order to identify the effects of alteration on the physical properties of Leg 129 basalts, the physical properties data were compared with major and trace element analyses of either the same samples used for physical properties determination or samples adjacent to the physical properties samples (typically within $0.15 \mathrm{~m}$ ). This comparison is supplemented further with a focused investigation of two cooling units (Units 9 and 24, Hole 801C) from the top of the lower section tholeiites at Site 801. Samples from Units 9 and 24 represent close to the extremes in the range in physical properties, and thus, it is extremely important to determine if there is any relationship between the progressive alteration from the interior to exterior of these units and the variations in physical properties and/or chemistry. In addition to comparing the major and trace elemental analyses with physical properties, thin sections were prepared for samples taken adjacent to physical properties samples in Unit 9.

The geochemical data used in this study were obtained by standard $\mathrm{X}$-ray fluorescence (XRF) and instrumental neutron activation (INA) techniques and by a hydrogen-nitrogen-carbon (HNC) analyzer. Detailed discussion of these data and procedures used during the analyses are presented elsewhere in this volume (Floyd and Castillo; Floyd et al.; Castillo et al.).

\section{PHYSICAL PROPERTIES VARIATIONS}

\section{Porosity and Density}

The basalts and dolerites recovered during Leg 129 display a wide variation in porosity with values ranging from $1 \%$ to $23 \%$ (Table 1 and Fig. 2). Well-defined depth-dependent trends in porosity are not evident at Sites 800 and 802 , partly because of the shallow penetration at these sites, although at Site 800 the porosity is noticeably higher in the extensively oxidized uppermost flow unit (Fig. 2). The porosity of the Site 802 basalts is distinctly lower, reflecting the fine-grained texture and lower degree of alteration of these rocks. The highest and lowest porosities were determined for rocks from Site 801. At this site porosity is high at the top of basement and immediately above and 


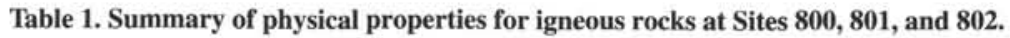

\begin{tabular}{|c|c|c|c|c|c|c|c|c|c|c|}
\hline $\begin{array}{l}\text { Core, section, } \\
\text { interval (cm) }\end{array}$ & $\begin{array}{l}\text { Depth } \\
\text { (mbsf) }\end{array}$ & $\begin{array}{c}\text { Cooling } \\
\text { unit }\end{array}$ & $\begin{array}{l}\text { Porosity } \\
(\%)\end{array}$ & $\begin{array}{l}\text { Wet-bulk } \\
\text { density } \\
\left(\mathrm{g} / \mathrm{cm}^{3}\right)\end{array}$ & $\begin{array}{l}\text { Grain } \\
\text { density } \\
\left(\mathrm{g} / \mathrm{cm}^{3}\right)\end{array}$ & $\begin{array}{l}\text { Velocity } \\
(\mathrm{km} / \mathrm{s})\end{array}$ & $\begin{array}{c}\text { Velocity } \\
\text { anisotropy } \\
(\%)\end{array}$ & $\begin{array}{l}\text { Thermal } \\
\text { conductivity } \\
(\mathrm{W} /[\mathrm{m} \bullet \mathrm{K}])\end{array}$ & Composition & Lithology \\
\hline \multicolumn{11}{|l|}{$129-800 \mathrm{~A}-$} \\
\hline $57 \mathrm{R}-1,22-24$ & 498.22 & 1 & 14.1 & 2.53 & \multirow[t]{2}{*}{2.78} & 4.03 & -1.6 & 1.68 & $\mathrm{AB} \mathrm{e}$ & Aphyric D \\
\hline $57 \mathrm{R}-1,87-89$ & 499.37 & 1 & 15.6 & 2.48 & & 4.54 & -1.0 & 1.81 & $\mathrm{AB} \mathrm{e}$ & Aphyric D \\
\hline $57 \mathrm{R}-2,98-100$ & 499.48 & 1 & 10.8 & 2.54 & \multirow[t]{4}{*}{2.72} & 4.66 & -3.1 & 1.92 & $\mathrm{AB} \mathrm{e}$ & Aphyric D \\
\hline $58 \mathrm{R}-1,49-51$ & 507.69 & 3 & 12.2 & 2.54 & & 4.66 & -2.0 & 1.65 & $\mathrm{AB} \mathrm{e}$ & Aphyric D \\
\hline $59 \mathrm{R}-1,7-9$ & 516.67 & 3 & 10.6 & 2.57 & & 4.65 & -1.5 & 1.61 & $\mathrm{AB} \mathrm{e}$ & Aphyric D \\
\hline $60 \mathrm{R}-1,44-46$ & 526.34 & 3 & 12.7 & 2.53 & & 4.28 & 3.2 & 1.70 & $\mathrm{AB} \mathrm{e}$ & Aphyric D \\
\hline $60 \mathrm{R}-1,69-71$ & 526.59 & 3 & 11.9 & 2.58 & 2.79 & 4.44 & -5.1 & 1.77 & $\mathrm{AB} \mathrm{e}$ & Aphyric D \\
\hline \multicolumn{11}{|l|}{ 129-801B- } \\
\hline $37 \mathrm{R}-1,56-58$ & 462.04 & 2 & 19.3 & 2.38 & \multirow[t]{3}{*}{2.70} & 3.46 & 1.1 & 1.50 & $\mathrm{AB} \mathrm{e}$ & Aphyric B \\
\hline $40 \mathrm{R}-1,38-40$ & 477.28 & 4 & 23.1 & 2.42 & & 3.81 & -1.6 & 1.65 & $\mathrm{AB} \mathrm{e}$ & Aphyric B \\
\hline $4 \mid R-2,95-97$ & 485.45 & 5 & 11.6 & 2.63 & & 4.84 & -2.1 & 1.76 & $\mathrm{AB} \mathrm{e}$ & Aphyric B \\
\hline $42 \mathrm{R}-2,95-97$ & 490.00 & 6 & 9.6 & 2.71 & \multirow[t]{2}{*}{2.89} & 4.84 & -0.8 & 1.75 & $\mathrm{AB} p$ & Aphyric D \\
\hline $43 \mathrm{R}-1,42-44$ & 492.62 & 7 & 12.7 & 2.61 & & 4.95 & -0.3 & 1.80 & $\mathrm{ABp}$ & Phyric B \\
\hline $43 \mathrm{R}-3,121-123$ & 496.19 & 9 & 9.8 & 2.63 & 2.81 & 5.11 & -1.0 & 1.80 & $\mathrm{AB} \mathrm{e}$ & Phyric B \\
\hline $44 \mathrm{R}-1,54-56$ & 502.24 & 12 & 10.2 & 2.65 & 2.83 & 4.77 & -1.4 & 1.67 & $\mathrm{AB} \mathrm{e}$ & Aphyric B \\
\hline \multicolumn{11}{|l|}{ 129-801C. } \\
\hline $1 \mathrm{R}-1,90-92$ & 494.60 & 1 & 9.5 & 2.67 & 2.84 & 4.59 & 0.2 & 1.82 & $\mathrm{ABp}$ & Aphyric micro-D \\
\hline $1 \mathrm{R}-3,82-84$ & 497.13 & 1 & 10.4 & 2.59 & 2.77 & 4.44 & -0.4 & 1.62 & $\mathrm{ABp}$ & Pl-s-phyric B \\
\hline $1 \mathrm{R}-5,29-31$ & 498.84 & 2 & 7.1 & 2.59 & 2.71 & 5.15 & -0.3 & \multirow[t]{3}{*}{1.91} & $\mathrm{AB} \mathrm{e}$ & Aphyric B \\
\hline $2 \mathrm{R}-1,14-16$ & 503.14 & 3 & 13.2 & 2.47 & 2.69 & 4.27 & 0.0 & & $\mathrm{AB} \mathrm{e}$ & Pl-s-phyric B \\
\hline $2 \mathrm{R}-2,81-83$ & 505.19 & 3 & 9.6 & 2.63 & 2.80 & 4.87 & 0.0 & & $\mathrm{AB} \mathrm{e}$ & Aphyric B \\
\hline $2 \mathrm{R}-4,76-78$ & 507.86 & 6 & 10.1 & 2.66 & 2.84 & 4.76 & 0.3 & 1.82 & $\mathrm{AB} \mathrm{e}$ & Pl-s-phyric B \\
\hline $3 \mathrm{R}-1,32-34$ & 512.52 & 7 & 18.7 & 2.38 & 2.69 & 3.75 & 0.1 & 1.60 & $\mathrm{AB} \mathrm{e}$ & Aphyric B \\
\hline 5R-1, 103-105 & 532.23 & 9 & 16.0 & 2.41 & 2.67 & 3.98 & -0.7 & 1.65 & TB p & Pl-h-megaphyric B \\
\hline $5 R-2,87-89$ & 533.33 & 9 & 14.0 & 2.53 & 2.77 & 4.51 & 0.5 & 1.65 & TB p & PI-m-megaphyric B \\
\hline $5 R-3,43-45$ & 534.20 & 9 & 10.8 & 2.64 & 2.84 & 4.99 & -0.1 & 1.73 & TB p & Pl-m-megaphyric B \\
\hline $6 \mathrm{R}-1,115-117$ & 541.65 & 16 & 23.0 & 2.37 & 2.78 & 3.69 & -1.5 & 1.69 & $\mathrm{~TB} \mathrm{p}$ & Pl-s-phyric B \\
\hline $6 \mathrm{R}-2,35-37$ & 542.14 & 16 & 2.4 & 2.80 & 2.85 & 5.99 & -0.1 & 1.74 & TB p & Aphyric D \\
\hline $6 \mathrm{R}-4,111-113$ & 545.76 & 20 & 20.3 & 2.36 & 2.70 & 3.77 & 0.7 & 1.49 & $\mathrm{~TB} p$ & Ol-pl-m-phyric B \\
\hline $6 \mathrm{R}-5,68-70$ & 546.71 & 21 & 1.7 & 2.94 & 2.98 & 6.31 & 0.0 & 1.94 & $\mathrm{~TB} \mathrm{e}$ & Ol-pl-s-microphyric B \\
\hline $7 \mathrm{R}-1,35-37$ & 550.45 & 21 & 1.3 & 2.96 & 2.99 & 6.33 & 0.3 & 2.02 & $\mathrm{~TB} \mathrm{e}$ & Aphyric B \\
\hline $7 R-2,37-39$ & 551.92 & 22 & 7.9 & 2.67 & 2.81 & 5.28 & -0.2 & 1.80 & TB e & Aphyric B \\
\hline $8 R-1,65-67$ & 560.15 & 24 & 18.8 & 2.47 & 2.81 & 4.11 & -0.1 & 1.60 & $\mathrm{~TB} \mathrm{e}$ & Aphyric B \\
\hline $8 \mathrm{R}-2,78-80$ & 561.35 & 24 & 1.0 & 2.97 & 2.99 & 6.59 & 0.0 & 1.95 & TB e & Aphyric B \\
\hline $9 \mathrm{R}-1,49-51$ & 563.69 & 25 & 3.3 & 2.86 & 2.92 & 6.37 & 0.3 & 2.10 & $\mathrm{~TB} \mathrm{e}$ & Aphyric B \\
\hline $9 \mathrm{R}-3,121-123$ & 567.15 & 25 & 2.5 & 2.88 & 2.93 & 6.08 & 1.2 & 1.95 & $\mathrm{~TB} \mathrm{e}$ & Aphyric B \\
\hline $9 R-4,137-139$ & 568.58 & 25 & 2.7 & 2.91 & 2.96 & 6.33 & -0.8 & 1.97 & TB e & Aphyric B \\
\hline $10 \mathrm{R}-2,55-57$ & 571.05 & 25 & 2.6 & 2.92 & 2.97 & 6.22 & 0.1 & 2.16 & TB e & Aphyric B \\
\hline $10 \mathrm{R}-5,3-5$ & 574.84 & 25 & 2.1 & 2.92 & 2.96 & 6.23 & 0.2 & 1.99 & $\mathrm{~TB} \mathrm{e}$ & Ol-s-microphyric B \\
\hline $10 R-6,65-67$ & 576.81 & 25 & 2.7 & 2.86 & 2.91 & 6.04 & -0.2 & 2.11 & $\mathrm{~TB} \mathrm{e}$ & Ol-s-microphyric B \\
\hline $11 \mathrm{R}-2,119-121$ & 580.49 & 27 & 2.9 & 2.85 & 2.91 & 6.10 & -0.2 & 2.24 & TB e & Ol-pl-s-microphyric B \\
\hline $11 \mathrm{R}-3,40-42$ & 581.20 & 28 & 2.3 & 2.87 & 2.91 & 6.30 & -0.4 & 2.43 & $\mathrm{~TB} \mathrm{e}$ & Aphyric B \\
\hline $12 \mathrm{R}-1,70-72$ & 588.00 & 31 & 9.4 & 2.59 & 2.75 & 5.01 & 0.1 & 1.75 & $\mathrm{~TB} \mathrm{e}$ & Aphyric B \\
\hline $12 \mathrm{R}-2,109-111$ & 589.89 & 32 & 2.1 & 2.92 & 2.96 & 6.18 & 0.3 & 1.79 & $\mathrm{~TB} \mathrm{e}$ & Aphyric B \\
\hline \multicolumn{11}{|l|}{$129-802 \mathrm{~A}-$} \\
\hline $58 \mathrm{R}-1.38-40$ & 516.38 & 2 & 1.9 & 2.93 & 2.97 & 6.22 & -0.8 & 2.01 & TB e & Aphyric B \\
\hline $58 \mathrm{R}-2,53-55$ & 518.03 & 2 & 2.5 & 2.88 & 2.92 & 5.97 & 0.4 & 2.00 & $\mathrm{~TB} \mathrm{e}$ & Aphyric B \\
\hline 58R-2, 105-107 & 518.55 & 3 & 2.6 & 2.92 & 2.97 & 5.94 & -0.1 & 1.86 & $\mathrm{~TB} \mathrm{e}$ & Microphyric B \\
\hline $58 \mathrm{R}-3,86-88$ & 519.86 & 5 & 6.3 & 2.82 & 2.94 & 5.34 & -1.3 & 1.85 & $\mathrm{~TB}$ e & Microphyric B \\
\hline $59 \mathrm{R}-1,83-85$ & 526.23 & 8 & 2.3 & 2.92 & 2.96 & 6.18 & 2.1 & 1.94 & TB e & Microphyric B \\
\hline $60 \mathrm{R}-1,90-92$ & 535.60 & 14 & 8.2 & 2.77 & 2.92 & 5.07 & 0.0 & 1.82 & $\mathrm{~TB} \mathrm{e}$ & Microphyric-aphyric B \\
\hline $62 \mathrm{R}-1,129-131$ & 551.89 & 17 & 1.2 & 2.94 & 2.97 & 6.20 & 0.0 & 2.09 & $\mathrm{~TB} \mathrm{e}$ & Microphyric B \\
\hline
\end{tabular}

Notes: $\mathrm{B}=$ basalt, $\mathrm{D}=$ dolerite, $\mathrm{AB}=$ alkali basalt, $\mathrm{TB}=$ tholeiitic basalt, $\mathrm{e}=$ evolved, $\mathrm{p}=$ primitive, $\mathrm{s}=$ sparsely, $\mathrm{m}=$ moderately, $\mathrm{h}=$ highly, ol $=$ olivine, $\mathrm{pl}=$ plagioclase .

below the hydrothermal deposit between 522 and 531 mbsf (Fig. 2). Consistently low porosities $(<3.5 \%)$ characterize the more evolved tholeiitic basalts below 560 mbsf at Site 801 .

A strong correlation $(r=-0.965)$ exists between porosity and wet-bulk density of the basalts from Sites 800,801 , and 802 (Fig. 3). The range in wet-bulk density is from 2.36 to $2.97 \mathrm{~g} / \mathrm{cm}^{3}$ (Table 1). The data shown in Figure 3 concentrate roughly in two groups. The area characterized by low porosity and high wet-bulk density consists of samples from Site 802 and the evolved tholeiitic basalts from the lower part of Hole $801 \mathrm{C}$, whereas higher porosity and lower wet-bulk density characterize the alkali basalts from Sites 800 and 801 and the more extensively altered tholeiites from Site 801.

A question which arises when examining the relationship between porosity and wet-bulk density, and also the relationships between the physical properties and chemistry of the basalts, is to what extent are the differences in physical and chemical parameters of the alkali and tholeiitic basalts governed by differences in magma type. For the alkali basalts the correlation coefficient $(r)$ for porosity and wet-bulk density is -0.881 and for the tholeiites $r=-0.973$. At the $5 \%$ significance level, the linear regressions of porosity on wet-bulk density for the alkali and 


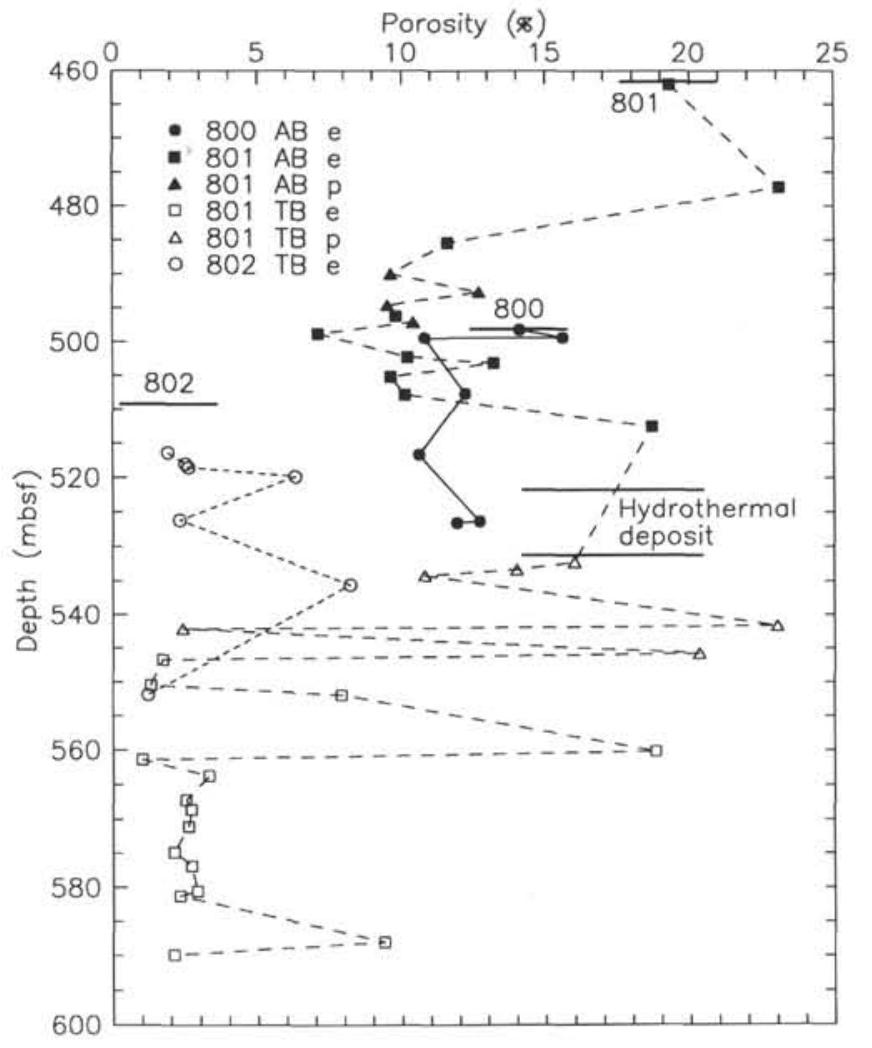

Figure 2. Porosity vs. depth at Sites 800,801 , and 802 . Note that in this figure and subsequent figures the samples are coded by site composition (alkalic vs. tholeiitic and evolved vs, primitive). Bars indicate the top of basement at the three sites and the depth range in which the hydrothermal deposit was recovered at Site 801.

tholeiitic basalts are characterized by no difference in the slopes of the lines but a significant difference in intercepts. One difference in the alkali basalt and tholeiite data sets that must be considered in this and subsequent comparisons is the relative extent of alteration. The alkali basalt samples analyzed were moderately to heavily altered, whereas the range in alteration for tholeiite samples is from slight to heavy.

The average grain density of the basalts analyzed ranges from 2.67 to $2.99 \mathrm{~g} / \mathrm{cm}^{3}$ (Table 1$)$. A moderately good correlation $(r=-0.837)$ exists between grain density and porosity (Fig. 4). Broken down by magma type, the $r$ values are -0.547 and -0.849 for the alkali and tholeiitic basalts, respectively, and the regression lines for the two data sets differ at the $5 \%$ significance level. The relationship between porosity and grain density is interpreted as one of the effects of alteration of the basalts, with the lower grain densities reflecting the greater abundance of smectitic clays $\left(2.0-2.7 \mathrm{~g} / \mathrm{cm}^{3}\right)$ and calcite $\left(2.7 \mathrm{~g} / \mathrm{cm}^{3}\right)$. Greater void space in the altered intervals and water bound to clay minerals contribute to the relationship between porosity and grain density. A similar association between porosity and grain density in oceanic crust has been documented by Broglia and Moos (1988) and Carlson and Herrick (1990).

To a minor extent, grain density variation reflects the compositional differences of the rocks (Table 1). Primitive alkalic basalts generally are more dense than their evolved counterparts, whereas the reverse is true for the tholeiitic basalts (Fig. 4). This divergent trend is due to the difference in timing of titanomagnetite $\left(4.9 \mathrm{~g} / \mathrm{cm}^{3}\right)$ crystallization in the alkalic and tholeiitic rock series. In the alkalic series, titanomagnetite is fractionated early so that continued magmatic differentiation would trend generally directly toward less dense evolved rocks enriched in alkalis

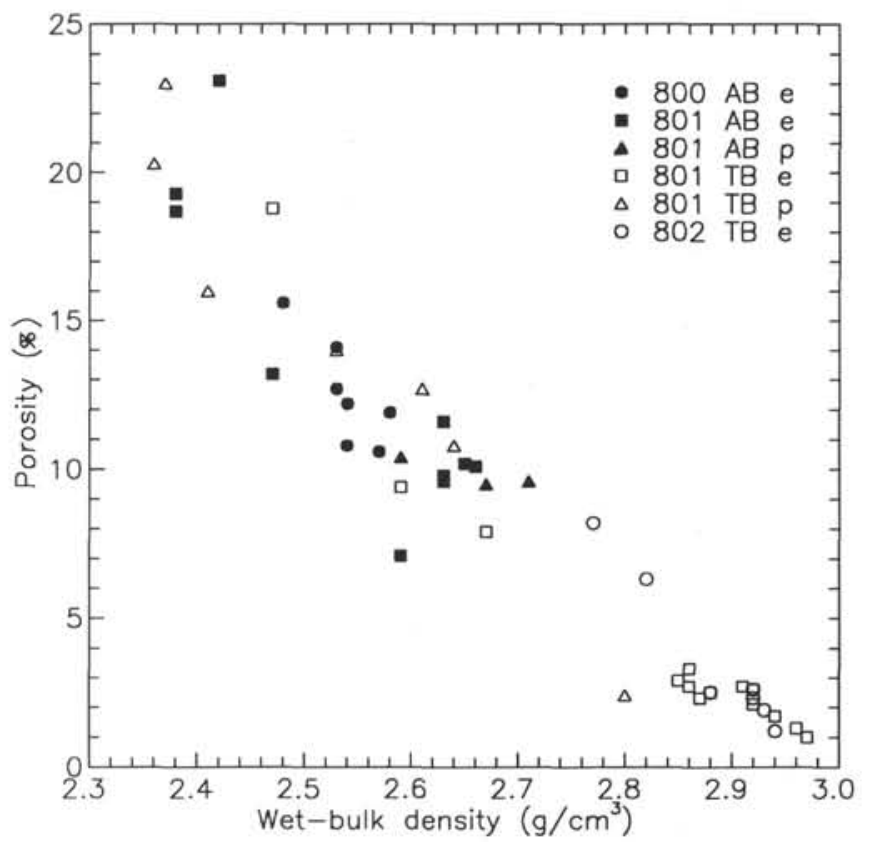

Figure 3. Wet-bulk density vs. porosity for the Leg 129 basalts.

(Fig. 5). On the other hand, titanomagnetite is fractionated later in the tholeiitic series, so that titanomagnetite is enriched in more evolved tholeiitic basalts first before trending toward less dense composition with continued differentiation.

\section{Compressional Wave Velocity}

As with porosity and density, the Leg 129 basalts display a wide variation in compressional wave velocity. The range for the velocity measurements is from 3.46 to $6.59 \mathrm{~km} / \mathrm{s}$ (Table 1). The variation in velocity displays a strong dependence on wet-bulk density (Fig. 6). Similar to the cross plot of porosity and wet-bulk density, the data concentrate in two areas with samples from Site 802 and Site 801 (below $560 \mathrm{mbsf}$ ) displaying a tight cluster with high density and high velocity. The trend for the variation of velocity with wet-bulk density roughly follows the relationship derived for Deep Sea Drilling Project (DSDP) basalts by Christensen and Salisbury (1975), with a noticeable fall off from their trend at lower velocities and bulk densities (Fig. 6). This deviation is in part a probable consequence of determining the compressional wave velocity at atmospheric pressure and the presence of open micro cracks in the samples. The relationship derived by Christensen and Salisbury (1975) is based on samples tested under $50 \mathrm{MPa}$ confining pressure. Newmark and Moos (1986) showed that for samples from DSDP Site 597, velocities determined at atmospheric pressure were nonsystematically lower by $2.4 \%$ to $9.7 \%$ than velocities determined at estimated in-situ pressures ranging from 44 to $46 \mathrm{MPa}$. The velocity of the bulk of the Leg 129 samples with velocities less than $5.4 \mathrm{~km} / \mathrm{s}$ is within $10 \%$ lower than the Christensen and Salisbury (1975) trend; however, some of the measurements exceed this range (Fig. 6). In addition to the effects of measuring velocity at atmospheric pressure, the low velocities may also reflect the presence of low-velocity materials, such as clay minerals, as has been suggested by Hamano (1979).

The trend and range of the velocity/wet-bulk density variation of the Leg 129 basalts follow those of the basalts recovered by previous DSDP Pacific legs (Fig. 7). The DSDP velocity data are primarily shipboard determinations performed at atmospheric pressure, and their variation with wet-bulk density is represented by range and delineated 


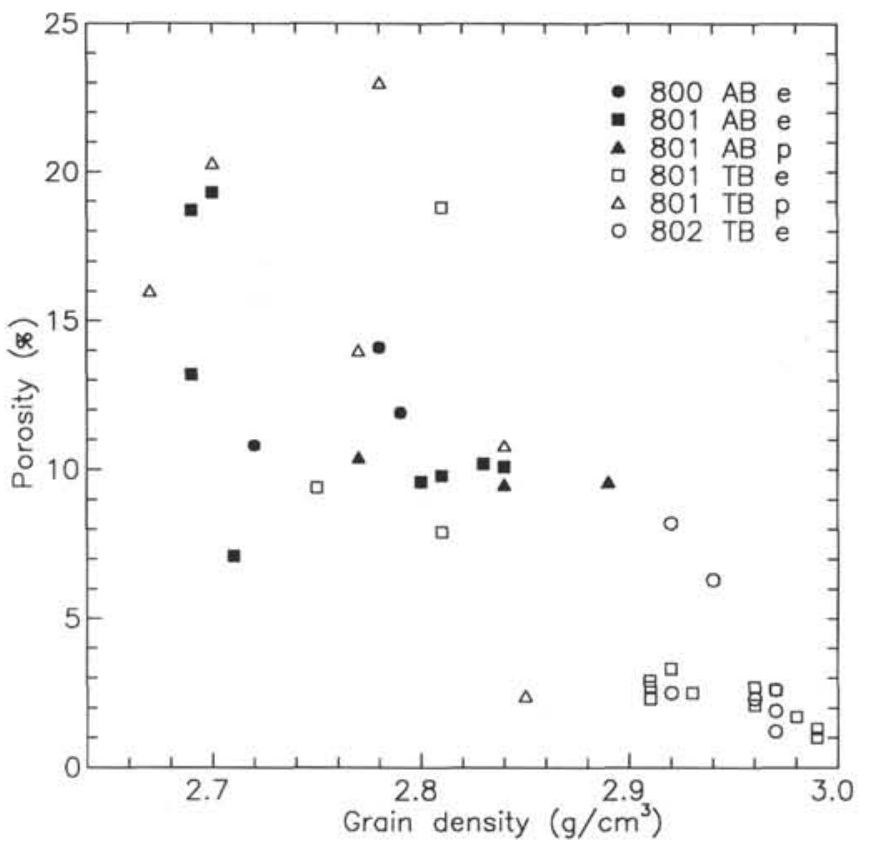

Figure 4. Grain density vs. porosity for the Leg 129 basalts.

by age in Figure 7 . Wet-bulk density and velocity were used to compare the physical properties of the Leg 129 samples with those from previous legs because for many of the older DSDP legs these are the only physical properties reported. What is interesting about the comparison of the Leg 129 and DSDP data is that the variation of the Jurassic crust samples from Site 801 spans the range for the total DSDP data set, with velocities and bulk densities as high as those of the youngest crustal samples.

Velocity anisotropy also displays a wide variation with values ranging from $-5.2 \%$ to $3.2 \%$ (Table 1 ). It does not vary systematically with depth or any of the other physical properties. Plotting anisotropy with compressional wave velocity (Fig. 8) reveals that the data concentrate in two fields. Samples with velocities less than $5.4 \mathrm{~km} / \mathrm{s}$, the alkali basalts and highly altered tholeiites, display a greater variation in velocity anisotropy with a mean and standard deviation of $-0.64 \%$ and $1.42 \%$, respectively. Samples with velocities greater than $5.9 \mathrm{~km} / \mathrm{s}$, which consist primarily of the tholeiites from Site 802 and the lowermost part of Hole 801C, are more nearly isotropic and display less variation. The average anisotropy for these samples is $0.12 \%$ with a standard deviation of $0.66 \%$.

Mineral and fracture orientation and fracture abundance were not measured for the velocity samples; however, the general patterns of these factors are consistent with the anisotropy variation. Most of the veinlets in the alkali basalts are oriented subhorizontal, whereas almost all of the veinlets in the more nearly isotropic tholeiitic basalts are randomly oriented. The veinlets in the heavily altered tholeiitic basalts from Site 801 , which display high anisotropy values, are randomly oriented, but these basalts also contain the highest number of veinlets. The alkali basalts from Site 801 contain the next highest concentration of veinlets. The Site 802 tholeiites are generally characterized by the lowest concentration of veinlets and low anisotropy. The highest values of velocity anisotropy are displayed by alkali basalts from Site 800 . These rocks contain randomly oriented, megascopic (up to $15 \mathrm{~mm}$ ) clinopyroxenes. Although they are randomly oriented, the large size of these crystals, relative to the size of the velocity samples, is most likely responsible for the high anisotropy values.

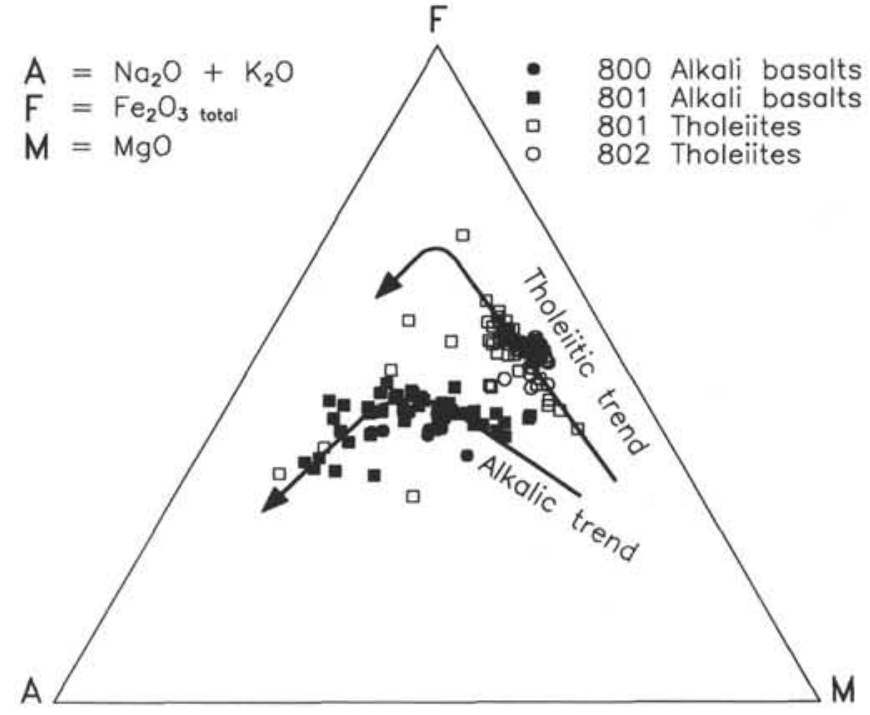

Figure 5. AFM diagram showing the differentiation trends for the Leg 129 alkalic and tholeiitic basalts.

\section{Thermal Conductivity}

Thermal conductivity values measured for the samples from Sites 800,801 , and 802 range from 1.49 to $2.43 \mathrm{~W} /(\mathrm{m} \cdot \mathrm{K})$ (Table 1$)$. Variation in thermal conductivity displays a general dependence on porosity (Fig. 9), with the greatest deviation from the trend of the data displayed by the samples with the highest conductivities. Scatter in the data at high thermal conductivities may in part reflect determination of these values by extrapolation beyond the range of conductivities of the calibration standards (Lancelot, Larson, et al., 1990). The trend of the thermal conductivity data roughly follows the relationship derived by Robertson and Peck (1974), with a displacement toward higher conductivity values (Fig. 9). The upward displacement shown in Figure 9 is interpreted to be an effect of alteration and extensive smectite replacement. A progressive increase in thermal conductivity with increasing hydrothermal alteration of basalts has been established from studies of deep drill holes in Iceland and Bermuda (Oxburgh and Agrell, 1982; Hyndman et al., 1979). Kono et al. (1980) suggested that differences in the mineralogical composition of alkalic and tholeiitic basalts from the Emperor Seamounts are responsible for the higher conductivity of the latter group of basalts. This pattern of variation is not evident for the Leg 129 basalts in the porosity range $(>5 \%)$ where data for alkalic and tholeiitic basalts overlap (Fig. 9).

\section{PHYSICAL PROPERTIES AND THE CHEMISTRY AND PETROGRAPHY OF BASALT ALTERATION}

The overall chemical and petrographic aspects of the alteration of the Leg 129 basalts are described by Floyd et al. (this volume) and Floyd and Castillo (this volume). Detailed secondary mineralogy and changes in chemical and oxygen isotopic compositions of Site 801 basalts are documented by Alt et al. (this volume), France-Lanord et al. (this volume), and Floyd and Rowbotham (this volume). The degree of alteration is commonly gauged by the amount of hydration $\left(\mathrm{H}_{2} \mathrm{O}+\right.$ content) and loss on ignition (LOI) of igneous rocks, and both of these parameters correlate fairly well for the Leg 129 basalts. With increasing LOI and $\mathrm{H}_{2} \mathrm{O}+$ content, the Leg 129 basalts display increases in contents of $\mathrm{K}_{2} \mathrm{O}, \mathrm{Fe}^{3+} / \mathrm{Fe}_{\mathrm{T}}, \mathrm{CO}_{2}, \mathrm{Cs}$, and $\mathrm{U}$, as well as $\mathrm{Na}_{2} \mathrm{O}$ and $\mathrm{Rb}$ to a certain extent, and decreases in concentrations of $\mathrm{SiO}_{2}$, 


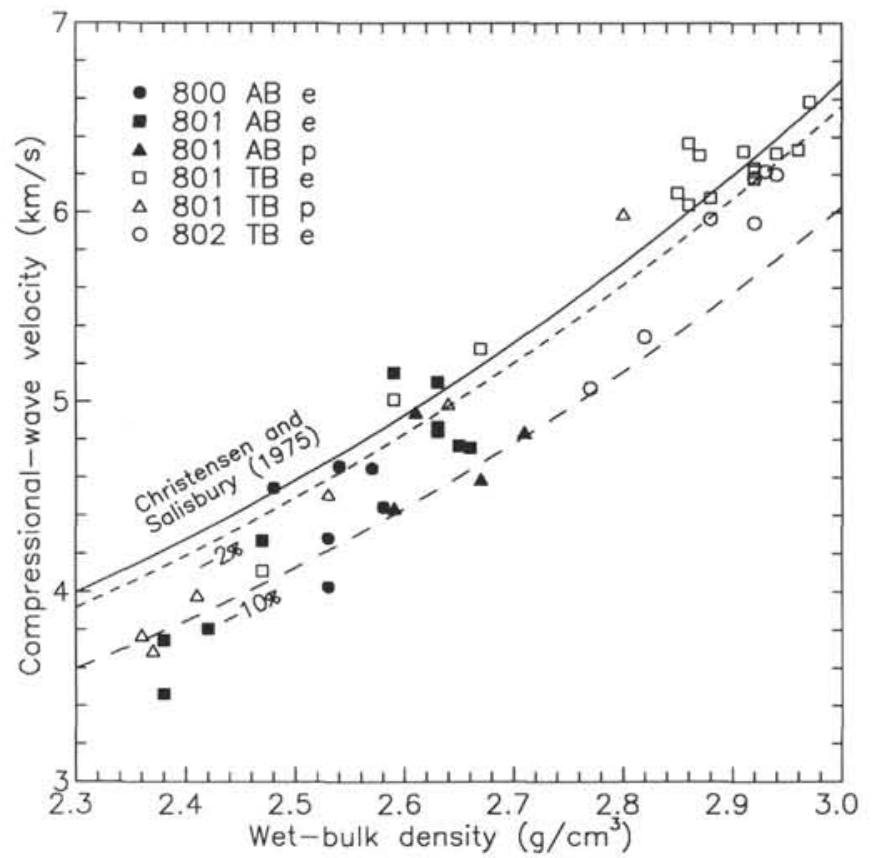

Figure 6. Wet-bulk density vs. compressional wave velocity for the Leg 129 basalts. The solid line plotted with the data is the nonlinear best fit for DSDP basalts at $50 \mathrm{MPa}$ from Christensen and Salisbury (1975). The short-dashed and long-dashed lines represent $-2 \%$ and $-10 \%$ displacements of the Christensen and Salisbury line, respectively.

$\mathrm{FeO}_{\mathrm{T}}, \mathrm{CaO}, \mathrm{MgO}$, and $\mathrm{Th}$. The concentrations of $\mathrm{TiO}_{2}, \mathrm{Al}_{2} \mathrm{O}_{3}, \mathrm{Nb}$, and Ta remain more or less constant. Almost all of these observations are consistent with the data collected by investigations of oceanic crust alteration (Cann, 1969; Hart, 1970; Hart et al., 1974; Humphris and Thompson, 1978; Edmond et al., 1979).

\section{Physical Properties and Alteration at Sites 800,801 , and 802}

The relationship between physical properties and the degree of alteration of the Leg 129 basalts was chosen to be represented by comparison of the compressional wave velocity with various elemental abundances expressed in terms of mass/volume. This normalized form of the chemical data was obtained by multiplying the element concentrations by the dry-bulk density ${ }^{6}$ of the samples. Expression of the elemental abundances in mass/volume units follows the approach of Hart (1973) in his study of relations between sonic velocity and basalt chemistry and that of investigators of chemical fluxes associated with basalt-seawater reactions (Humphris and Thompson, 1978). The mass/volume units are preferable because they represent the actual amount of an element in the rock, unlike the weight-percent concentration units which do not account for the porosity of the rock. Compressional wave velocity was chosen as the physical properties parameter in the comparison because of its widespread use in evaluating the physical state of oceanic crust. Velocity and dry-bulk density are strongly correlated for the Leg 129 basalts $(r=-0.974)$; however, with the exception of $\mathrm{SiO}_{2}, \mathrm{Al}_{2} \mathrm{O}_{3}$, and $\mathrm{MgO}$, this correlation does not significantly affect the velocity/element correlations. For most elements the correlation between velocity and element abundance in mass/volume units is slightly less than the correlation between velocity and element concentration. Using the mass/volume units, correlations between velocity and $\mathrm{SiO}_{2}$ and velocity and $\mathrm{MgO}$ increase

${ }^{6}$ Dry-bulk density $=(1-$ fractional porosity $) \times$ grain density.

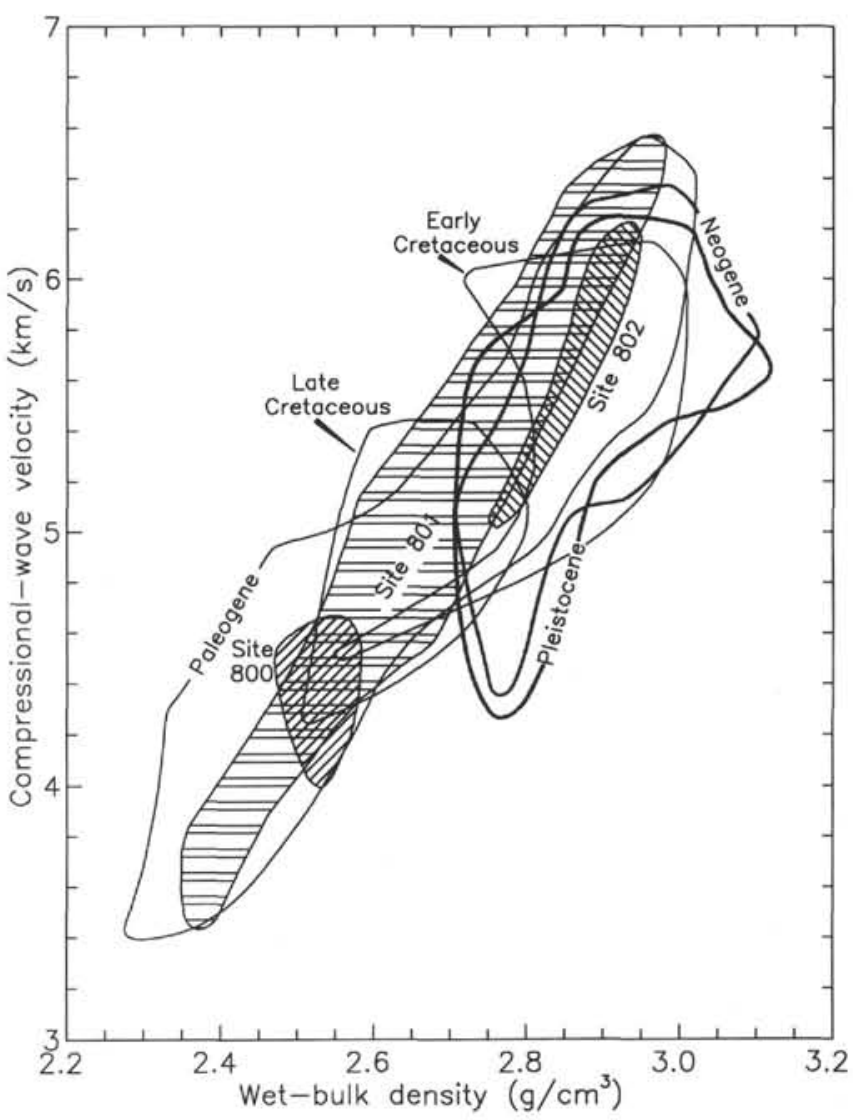

Figure 7 . Wet-bulk density vs, compressional wave velocity for previously reported Pacific plate sites (by age) with fields for data from Sites 800,801 , and 802 superimposed. Data are results from shipboard analyses, except where noted by an asterisk. Data sources include: (1) Pleistocene: East Pacific Rise Sites 421, 422, 427, and 428 (Rosendahl, Hekinian, et al., 1980); Gulf of California Sites 478, 481, 482, and 485 (Curray, Moore, et al., 1982; Lewis, Robinson, et al., 1983); Costa Rica Rift Sites 506, 507, and 508 (Honnorez, von Herzen, et al., 1983); (2) Neogene: Nazca Plate Site 319* (Christensen, 1976); East Pacific Rise Sites 420 and 425 (Rosendahl, Hekinian, et al., 1980); Gulf of California Site 483 (Lewis, Robinson, et al., 1983); Costa Rica Rift Sites 504B and 510 (Cann, Langseth, Honnorez, von Herzen, White, et al., 1983; Honnorez, von Herzen, et al., 1983; Anderson, Honnorez, Becker, et al., 1985; Leinen, Rea, et al., 1986); (3) Paleogene: Panama Basin Site 155* (Christensen, 1973); Nazca Plate Sites 320* and 321* (Christensen, 1976); Southeast Pacific Site 322* (Salisbury and Christensen, 1976); North Pacific Sites 430, 432, and 433 (Jackson, Koisumi, et al., 1980); Central Pacific Site 597 (Leinen, Rea, et al., 1986); (4) Late Cretaceous: Central Pacific Site 163* (Christensen, 1973); Southeast Pacific Site 323* (Salisbury and Christensen, 1976); and (5) Early Cretaceous: Nauru Basin Site 462 (Larson, Schlanger, et al., 1981; Moberly, Schlanger, et al., 1986); North Pacific Site 465* (Christensen et al., 1981); Southwest Pacific Site 595 (Duennebier, Stephen, Gettrust, et al., 1987).

significantly and the correlation between velocity and $\mathrm{Al}_{2} \mathrm{O}_{3}$ decreases significantly.

Variation of compressional wave velocity as a function of the major element chemistry of the Leg 129 basalts is shown in Figure 10. Correlation coefficients for the relationships shown in Figure 10 are provided in Table 2. Values listed in Table 2 include separate coefficients for alkali and tholeiitic basalts, as well as coefficients for the combined basalt data set. For the total data set, at the $5 \%$ significance level, velocity correlates positively with $\mathrm{FeO}, \mathrm{CaO}, \mathrm{MgO}, \mathrm{MnO}$, and $\mathrm{SiO}_{2}$, all components that are lost during progressive alteration of 
Table 2. Correlation coefficients for relationships between compressional wave velocity and major and trace elements.

\begin{tabular}{|c|c|c|c|c|c|c|}
\hline & \multicolumn{2}{|c|}{ Alkali basalts } & \multicolumn{2}{|c|}{ Tholeiitic basalts } & \multicolumn{2}{|c|}{ All basalts } \\
\hline & $\begin{array}{c}\text { Number } \\
\text { of samples }\end{array}$ & $\begin{array}{l}\text { Correlation } \\
\text { coefficient }(r)\end{array}$ & $\begin{array}{c}\text { Number } \\
\text { of samples }\end{array}$ & $\begin{array}{l}\text { Correlation } \\
\text { coefficient }(r)\end{array}$ & $\begin{array}{l}\text { Number } \\
\text { of samples }\end{array}$ & $\begin{array}{c}\text { Correlation } \\
\text { coefficient }(r)\end{array}$ \\
\hline $\mathrm{SiO}_{2}$ & 19 & -0.200 & 24 & ${ }^{a} 0.873$ & 43 & ${ }^{2} 0.860$ \\
\hline $\mathrm{CaO}^{2}$ & 19 & ${ }^{\mathrm{a}} 0.834$ & 24 & ${ }^{a} 0.777$ & 43 & ${ }^{2} 0.878$ \\
\hline $\mathrm{FeO}$ & 19 & ${ }^{a} 0.747$ & 23 & ${ }^{2} 0.895$ & 42 & ${ }^{\mathrm{a}} 0.897$ \\
\hline $\mathrm{MgO}$ & 19 & 0.342 & 24 & ${ }^{\mathrm{A}} 0.839$ & 43 & ${ }^{2} 0.728$ \\
\hline $\mathrm{MnO}$ & 19 & ${ }^{\mathrm{a}} 0.538$ & 24 & "0.810 & 43 & ${ }^{\mathrm{a}} 0.532$ \\
\hline $\mathrm{Na}_{2} \mathrm{O}$ & 19 & ${ }^{\mathrm{a}} 0.706$ & 24 & 0.377 & 43 & -0.053 \\
\hline $\mathrm{K}_{2} \mathrm{O}$ & 19 & ${ }^{\mathrm{a}}-0.606$ & 24 & ${ }^{2}-0.601$ & 43 & " -0.789 \\
\hline $\mathrm{Fe}^{3+} / \mathrm{Fe}_{\mathrm{T}}$ & 19 & a -0.807 & 23 & ${ }^{a}-0.867$ & 42 & ${ }^{a}-0.810$ \\
\hline $\mathrm{H}_{2} \mathrm{O}+$ & 19 & -0.317 & 23 & -0.770 & 42 & a -0.784 \\
\hline LOI & 19 & 0.391 & 24 & ${ }^{a}-0.603$ & 43 & ${ }^{a}-0.540$ \\
\hline $\mathrm{Al}_{2} \mathrm{O}_{3}$ & 19 & 0.107 & 24 & 0.156 & 43 & 0.074 \\
\hline $\mathrm{TiO}_{2}$ & 19 & 0.196 & 24 & 0.368 & 43 & -0.367 \\
\hline $\mathrm{CaCO}_{3}$ & 19 & 0.368 & 18 & ${ }^{a}-0.523$ & 37 & -0.161 \\
\hline $\mathrm{CO}_{2}$ & 19 & ${ }^{\mathrm{a}} 0.476$ & 23 & -0.211 & 42 & 0.097 \\
\hline $\mathrm{Rb}$ & 19 & -0.397 & 24 & -0.745 & 43 & ${ }^{a}-0.779$ \\
\hline $\mathrm{Ba}$ & 19 & 0.378 & 24 & -0.381 & & \\
\hline $\mathrm{Sr}$ & 19 & ${ }^{\mathrm{a}} 0.600$ & 24 & 0.2 .36 & & \\
\hline Cs & 10 & 0.615 & 14 & -0.329 & 24 & -0.194 \\
\hline $\mathrm{La}$ & 10 & -0.531 & 14 & 0.513 & & \\
\hline $\mathrm{Ce}$ & 10 & -0.587 & 14 & 0.507 & & \\
\hline $\mathrm{Yb}$ & 10 & ${ }^{\mathrm{a}} 0.700$ & 14 & 0.672 & 24 & ${ }^{a} 0.758$ \\
\hline $\mathrm{Lu}$ & 10 & ${ }^{\mathrm{a}} 0.679$ & 14 & 0.708 & 24 & ${ }^{2} 0.781$ \\
\hline
\end{tabular}

${ }^{a}$ Correlation significant at the $5 \%$ level.

basalt. Conversely, velocity correlates negatively with $\mathrm{K}_{2} \mathrm{O}, \mathrm{Fe}^{3+} / \mathrm{Fe}_{\mathrm{T}}$, $\mathrm{H}_{2} \mathrm{O}+$, and LOI, components that are gained during alteration. The tholeiitic basalts are characterized by the same significant correlations that characterize the total data set (Table 2). For the alkali basalts the only statistically significant correlations are the positive correlations between velocity and $\mathrm{CaO}, \mathrm{FeO}, \mathrm{MnO}$, and $\mathrm{Na}_{2} \mathrm{O}$ and the negative correlations between velocity and $\mathrm{K}_{2} \mathrm{O}$ and $\mathrm{Fe}^{3+} / \mathrm{Fe}_{\mathrm{T}}$. For those correlations which are significant for both magma types (velocity and $\mathrm{FeO}, \mathrm{CaOMnO}, \mathrm{K}_{2} \mathrm{O}$, and $\mathrm{Fe}^{3+} / \mathrm{Fe}_{\mathrm{T}}$ ), the difference in regression lines for the alkali and tholeiitic basalts is statistically significant for all except the regression of $\mathrm{K}_{2} \mathrm{O}$ on compressional wave velocity.

Compressional wave velocity was compared with concentrations of $\mathrm{CaCO}_{3}$ and $\mathrm{CO}_{2}$ in an attempt to evaluate the potential influence of calcification of the Leg 129 basalts. Alt et al. (this volume) noted that the Site 801 basalts have more calcite than young crust, such as at Hole 504B near the Costa Rica Rift in the eastern equatorial Pacific. This observation is consistent with the interpretation that calcite formation increases with the age of the crust, but this notion is indirectly based on the higher $\mathrm{CO}_{2}$ content of older crust than that of younger crust (e.g., Staudigel et al., 1981). Data for $\mathrm{CaCO}_{3}$ are from all three sites, with limited representation of the Site 801 tholeiites, but data for $\mathrm{CO}_{2}$ are available for all the samples being considered. The comparisons of velocity with $\mathrm{CaCO}_{3}$ and $\mathrm{CO}_{2}$ are inconclusive (Fig. 11). The only significant correlations are a weak positive correlation between velocity and $\mathrm{CO}_{2}$ for the alkali basalts and a weak negative correlation between velocity and $\mathrm{CaCO}_{3}$ for the tholeiitic basalts (Table 2). Interpretation of the results of these comparisons of compressional wave velocity with $\mathrm{CaCO}_{3}$ and $\mathrm{CO}_{2}$ must be viewed in the context of the sample scale. Calcite commonly occurs as vein fillings, and as a consequence the effects of progressive calcification with aging of the basalts may be better reflected in the properties on a scale of $1 \mathrm{~m}$ to tens of meters.

Variation of compressional wave velocity as a function of selected trace and rare elements is shown in Figure 12. Significant correlations for the relationships shown in Figure 12 include the negative correlation between velocity and $\mathrm{Rb}$ for the tholeiites, the positive correlation between velocity and $\mathrm{Sr}$ for the alkali basalts, and for both alkali and tholeiitic basalts, positive correlations between velocity and $\mathrm{Yb}$ and $\mathrm{Lu}$ (Table 2). Regression lines for the alkali and tholeiitic basalts for both the regressions of $\mathrm{Yb}$ and $\mathrm{Lu}$ on velocity do not differ at the 5\% significance level. Because of the large differences in the concentrations of $\mathrm{Ba}, \mathrm{Sr}, \mathrm{La}$, and $\mathrm{Ce}$ for the alkali and tholeiitic basalts, correlation coefficients for these elements have little meaning for the total data set. For the other trace and rare earth elements the combined basalt data display a significant negative correlation between velocity and $\mathrm{Rb}$ and significant positive correlations between velocity and $\mathrm{Yb}$ and $\mathrm{Lu}$.

\section{Alteration of Units 9 and 24 (Hole 801C)}

Unit 9 is a thin lava flow ( $\approx 3.7 \mathrm{~m}$ thick), or possibly a large pillow lava. It is located directly underneath the hydrothermal deposit and above a pile of small $(<1-\mathrm{m}$ diameter) pillow lavas. The unit belongs to the primitive group of tholeiitic basalts at Site 801 (Floyd and Castillo, this volume). This group comprises some samples that have the highest $\mathrm{MgO}$, $\mathrm{Ni}$, and $\mathrm{Cr}$, as well as lowest incompatible element (e.g., rare earth elements, $\mathrm{Ta}$ and $\mathrm{Zr}$ ) concentrations among the tholeitic samples analyzed. Unit 9 is a moderately plagioclase megaphyric basalt consisting of variable amounts (up to $10 \%$ ) of phaneritic (up to $5 \mathrm{~mm}$ ) plagioclase set in a fine-grained matrix of feldspars and secondary minerals. It is the most altered igneous unit (up to $100 \%$ ) at Site 801 . Its color ranges from brownish green at the top, because of later oxidative alteration (Floyd and Castillo, this volume), to light gray in the center and greenish gray at the base. As a whole, the unit belongs to the intensely altered blue-green zone described in detail by Alt et al. (this volume). Alteration is patchy and most intense near the brecciated zones that served as conduits for solutions feeding the hydrothermal deposit above the unit. However, in general, alteration is most intense at the top compared to its central and bottom parts. This type of alteration pattern is typical of altered pillow lavas on the seafloor (Paster, 1968; Cann, 1969, 1971; Humphris and Thompson, 1978).

Thin sections were prepared for samples from the bottom (Sample 129-801C-5R-3, 38-43 cm), center (Sample 129-801C-5R-2, 110-115 $\mathrm{cm}$ ), and top (Samples 129-801C-5R-1, 110-114 cm, and 129-801C-5R$1,124-125 \mathrm{~cm}$ ) of Unit 9 . The bottom sample is a plagioclase glomerophyric basalt containing about $3 \%$ plagioclase phenocrysts. The phenocrysts range in size from $\approx 0.1$ to $3.0 \mathrm{~mm}$, but form clusters as large as $\approx 5.0 \mathrm{~mm}$, giving the rock its characteristic plagioclase megaphyric appearance. The phenocrysts are typically fractured and anhedral because 


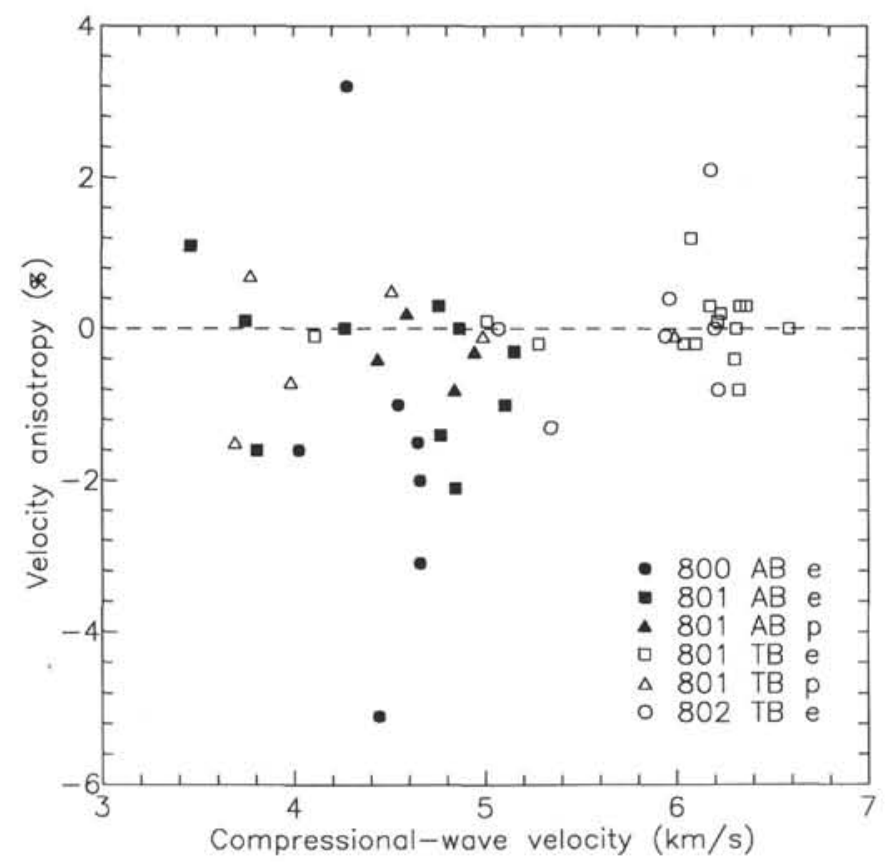

Figure 8. Compressional wave velocity (vertical) vs. velocity anisotropy for the Leg 129 basalts.

of their resorbed as well as serrated boundaries. Some of the fractures could have been post-solidification features as some of these, now filled with clays and calcite, are contiguous in the matrix. The composition of the phenocrysts, determined by extinction-angle measurements (Kerr, 1977), is $\mathrm{An}_{40-80}$, but all crystals are oscillatory zoned and have sodic rims. Almost all the phenocrysts also have minute $(<0.01 \mathrm{~mm})$ devitrified glass inclusions that show slight preferred concentrations parallel to crystal outline. The groundmass is fine-grained $(<0.25 \mathrm{~mm})$ and is subophitic to hyalophitic in texture, although all the interstitial glass and almost all $(>50 \%)$ of the ferromagnesians are now altered to smectitic clays, with traces of zeolite and calcite. In contrast to the phenocrysts, groundmass plagioclase is acicular and skeletal in habit and has quenched texture. It is also more sodic in composition $\left(\mathrm{An}_{35-65}\right)$ than the phenocrystic plagioclase. These compositional and textural differences suggest that the phenocryst is most probably not in equilibrium with the silicate melt, and is xenocrystic. The interstitial clinopyroxenes range from variolitic to allotriomorphic-granular in texture, but are now almost completely fibrous because of alteration. Groundmass olivine is recognized only by brownish patches of clays and calcite that sporadically preserve its euhedral crystal outline. Minute, deep red to brown euhedral grains of spinel are ubiquitous in the thin section, and these grains are most probably responsible for the high $\mathrm{Cr}$ content $(\approx 340 \mathrm{ppm})$ of the sample.

Samples from the center (Sample 129-801C-5R-2, 110-115 cm) and near the top (Sample 129-801C-5R-1, 124-125 cm) of Unit 9 are very similar in petrographic characteristics. Both are more altered and greener in color than the basal sample because of the presence of more calcite, glauconite, and green clay (celadonite?). These samples are still plagioclase phyric $(\approx 2 \%$ phenocrysts $)$ basalts, but their groundmass is now $80 \%$ altered. Moreover, even the phenocrystic plagioclase is normally altered along the margins or central parts, with some completely altered, leaving only outlines of entire glomerocrysts. This alteration is most probably the reason why the smaller $(<1 \mathrm{~mm})$, isolated phenocrysts present in the basal sample are almost completely absent in the two samples from the central and upper part of the unit. The minute, devitrified glass inclusions in the phenocrysts are also slightly larger and commonly coalesce in the two more altered samples compared to those of the basal sample. The groundmass in

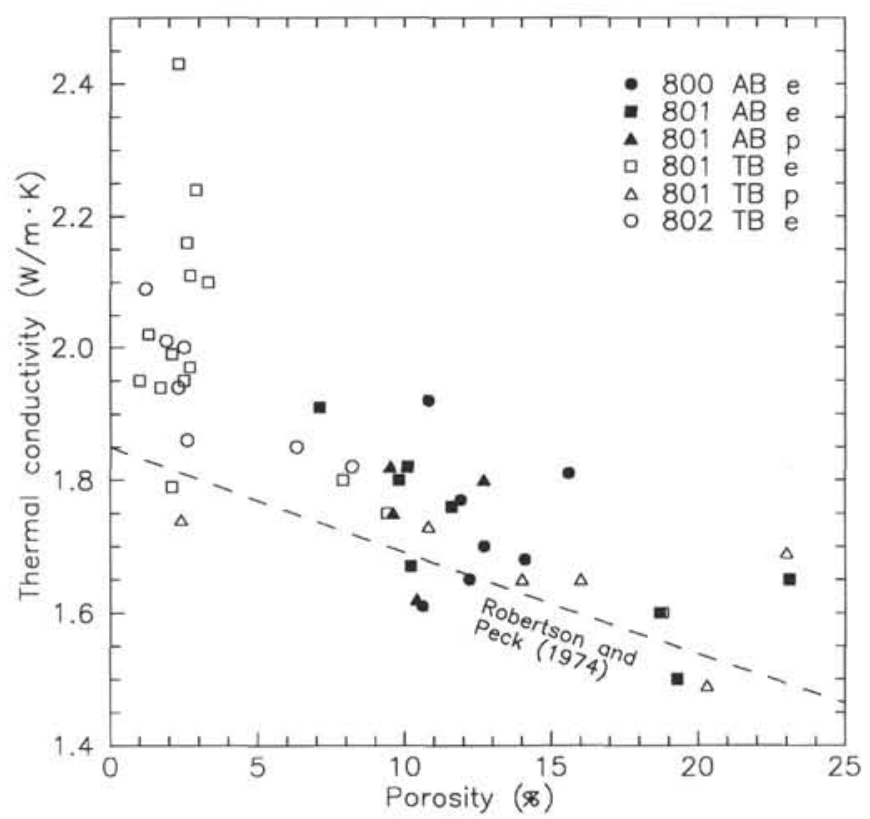

Figure 9. Porosity vs. thermal conductivity for the Leg 129 basalts. The line plotted with the data is the empirical relationship, $K=(1.36-0.60 \phi)^{2}$ (after Hyndman et al., 1984) between porosity $(\phi)$ and thermal conductivity $(K)$ for basalts with $7 \%$ olivine from Robertson and Peck (1974).

the center and near top samples is almost completely reduced to remnants of skeletal plagioclase and clumps of dark-brown to black opaques (spinel and sphene surrounded by Fe-oxyhydroxides) floating in a matrix of clay and cloudy calcite. Irregular veinlets (a few tens of microns wide) filled and/or lined with Fe-oxyhydroxide and celadonite are also present in the altered groundmass.

Sample 129-801C-5R-1, 110-114 cm, also from near the top of Unit 9 , is a $100 \%$ replaced rock representing the extreme case of alteration of the unit. The sample analyzed for physical properties and chemistry (Sample 129-801C-5R-1, 103-105 cm) has petrographic features that are transitional between this sample and the previously described near-top sample (Sample 129-801C-5-1, 124-125 cm) Sample 129-801C-5R-1, 110-114 cm is an aggregate of micritic- and bladed to almost fibrous sparry-calcite $(70 \%)$, glauconite, celadonite, and brown clay $(20 \%)$, and Fe-oxyhydroxide ( $10 \%)$. The only recognizable Unit 9 features in this sample are a few outlines of plagioclase phenocrysts that are completely pseudomorphed by calcite.

Unit 24 is a thin lava flow or a thick pillow lava ( $\approx 3 \mathrm{~m}$ thick) located approximately $23 \mathrm{~m}$ below the hydrothermal deposit. It belongs to an evolved group of tholeiitic lavas, which on the average, has relatively lower $\mathrm{MgO}, \mathrm{Ni}$, and $\mathrm{Cr}$ contents but higher incompatible element concentrations than the primitive group. The unit is an aphyric basalt with hypohyaline top and bottom margins and a hypocrystalline interior. Based on megascopic examination and on trace element concentration, the least altered interior of Unit 24 is also less altered compared to that of Unit 9, and Unit 24 is intensely fractured only at its uppermost part. It is greenish gray in color with oxidation stains at the top and a slightly darker gray bottom. Similar to Unit 9 , its top is more altered relative to its bottom. Sample 129-801C-8R-1, 101-106 cm, was taken from the heavily altered top of Unit 24, whereas Sample 129-801C-8R-2, 69-74 cm, is from the less altered interior of the unit.

The significant change in physical properties from unaltered to altered regions of Units 9 and 24 marks close to the extremes in the ranges for the properties of the Leg 129 basalts. Going from the fresh interior of the units to the more altered tops, velocity decreases from 4.97 to $3.98 \mathrm{~km} / \mathrm{s}$ in Unit 9 and 6.59 to $4.09 \mathrm{~km} / \mathrm{s}$ in Unit 24 (Table 1). The corresponding changes in porosity and wet-bulk density that 
accompany the transition from fresh to altered regions are $10.8 \%$ to $16.0 \%$ and 2.62 to $2.35 \mathrm{~g} / \mathrm{cm}^{3}$ in Unit 9 and $1.0 \%$ to $18.8 \%$ and 2.97 to $2.47 \mathrm{~g} / \mathrm{cm}^{3}$ in Unit 24 . The higher porosity and lower wet-bulk density of the "fresh" part of Unit 9 relative to that of the interior of Unit 24 reflects the overall higher degree of alteration those basalts, including Unit 9, which lie immediately below the hydrothermal deposit at Site 801.

Results of the chemical analyses of the samples from Units 9 and 24 are presented in Table 3 along with the alteration trends for these units on a mass/volume basis. For those elements that display significant correlations with compressional wave velocity for the tholeitic basalts (Table 2), comparable trends are seen for Units 9 and 24 in the changes from the less altered (higher velocity) parts of the units to the more altered (lower velocity) parts of the units. Going from the fresh to altered parts of the units, these changes include decreases in the normalized abundance of $\mathrm{SiO}_{2}, \mathrm{FeO}, \mathrm{MnO}, \mathrm{MgO}, \mathrm{CaO}, \mathrm{Yb}$, and $\mathrm{Lu}$ and increases in $\mathrm{K}_{2} \mathrm{O}, \mathrm{Fe}^{3+} / \mathrm{Fe}_{\mathrm{T}}$, LOI, $\mathrm{H}_{2} \mathrm{O}+$, and $\mathrm{Rb}$ (Table 3 and Figs. 10 and 12). In Unit 9 the changes of $\mathrm{SiO}_{2}, \mathrm{CaO}$, and $\mathrm{LOI}$ are nonsystematic, not following a continuous trend. Elements that do not display a significant correlation with compressional wave velocity for the tholeiitic basalts and which are characterized little or no change in Units 9 and 24 include $\mathrm{TiO}_{2}, \mathrm{La}$, and $\mathrm{Ce}$. Barium displays no correlation with velocity for the total tholeiitic data set but is characterized by increasing abundance with increasing alteration in both Units 9 and 24. The abundances of $\mathrm{Al}_{2} \mathrm{O}_{3}, \mathrm{Na}_{2} \mathrm{O}$, and $\mathrm{Sr}$ do not correlate with compressional wave velocity for the total data set and are characterized by little change in Unit 24; however, in Unit 9 these elements decrease in abundance going from fresh to altered regions. Cesium also displays little change in Unit 24 and does not correlate with velocity for the tholeiites as a whole but increases with increasing alteration in Unit 9. Other trends with increasing alteration that characterize Units 9 and 24 include decreases in $\mathrm{Cu}, \mathrm{Ni}, \mathrm{S}$, and $\mathrm{Zn}$ and an increase in U. Vanadium decreases nonsystematically with increasing alteration in Unit 9, whereas in Unit 24 it displays little change. The lack of patterns for the variation of compressional wave velocity with $\mathrm{CO}_{2}$ and $\mathrm{CaCO}_{3}$ contents that characterizes the total basalt data set is also reflected in the variation of these components in Units 9 and 24. With increasing alteration $\mathrm{CO}_{2}$ decreases in Units 9 and 24, whereas $\mathrm{CaCO}_{3}$ varies irregularly in Unit 9 and increases with increasing alteration in Unit 24.

\section{DISCUSSION AND SUMMARY}

The physical properties of the basement rocks sampled from the Pigafetta and East Mariana basins during Leg 129 display a wide range of values and consistent relationships between the properties. The range in the properties, as reflected by the variation in wet-bulk density and compressional wave velocity, spans the range for the freshest to most altered basalts reported from previous Pacific DSDP legs. Basalts from Site 802 and the lower part of the evolved tholeiitic sequence at Site 801 display the lowest porosity and highest wet-bulk density, compressional wave velocity, and thermal conductivity. The more altered basalts immediately above and below the hydrothermal deposit at Site 801 represent the other extreme in the range of physical properties. The basalts and dolerites from Sites 800, 801, and 802 display variations in wet-bulk density, compressional wave velocity (based on its relationship with wet-bulk density), and thermal conductivity that are primarily controlled by variations in porosity. The negative correlation between porosity and average grain density most likely reflects compositional changes that accompany the early phases of alteration, particularly the increase in abundance of hydrous smectitic clays. To a lesser extent increased clay abundance may also contribute to low compressional wave velocity values and high values measured for thermal conductivity.

The cross plots of the various physical properties (Figs. 3, 4, 6, 8, and 9) and the velocity/chemistry plots (Figs. 10, 11, and 12) are generally characterized by concentration of data in two groups, the alkali and highly altered tholeiitic basalts and the less altered tholeiitic basalts. This separation suggests that differences in magma type largely govern the differing trends exhibited by the alkali and tholeiitic basalts. This idea is supported by the results of the velocity/chemistry comparisons, in which regression lines for the two basalt types differ significantly for all but the regressions of $\mathrm{K}_{2} \mathrm{O}, \mathrm{Yb}$, and $\mathrm{Lu}$ on compressional wave velocity. However, because of the differences in the range in the degree of alteration displayed by the alkali and tholeiitic basalts it is difficult to make conclusions concerning the control of magma type on the trends. Alteration of the tholeiites ranges from slight to nearly $100 \%$, whereas the alkali basalts are generally moderately to heavily altered. It is reasonable to expect that regression relationships derived for the alkali basalts would change to some extent if results from the analysis of slightly altered samples were included in the data set.

Variation in compressional wave velocity (and by association, the other physical properties) is consistent with the alteration trends indicated by variation in major and trace element chemistry. The relationships between velocity and the alteration trends are evident for samples from all three Leg 129 sites, viewed as a whole, and for two cooling units in Hole 801C (Units 9 and 24), which were sampled from their least altered interiors to more heavily altered margins. The main alteration phases in the Leg 129 basalts are hydrous smectitic clays and celadonite (K-Fe mica). As samples from Unit 9 in Hole $801 \mathrm{C}$ show, clay minerals in some instances are the most abundant constituent of the highly altered basalts. The increase in abundance of these components, represented by the concentrations of $\mathrm{H}_{2} \mathrm{O}+$, is associated with a distinct decrease in velocity. Increasing $\mathrm{K}_{2} \mathrm{O}$ and $\mathrm{Rb}$ contents accompany increases in celadonite abundance (Alt et al., this volume) and are also negatively correlated with velocity. Alteration of plagioclase and ferromagnesians, which can be extensive as evidenced in Unit 9 samples, is accompanied by losses of $\mathrm{CaO}$ and $\mathrm{MgO}$, respectively, and both $\mathrm{CaO}$ and $\mathrm{MgO}$ display significant positive correlations with compressional wave velocity. Oxidation of the secondary clays and other basalt components increases with increasing degree of alteration and is responsible for the strongly negative correlation between velocity and $\mathrm{Fe}^{3+} / \mathrm{Fe}_{\mathrm{T}}$. The positive correlation of velocity and $\mathrm{Yb}$ and Lu for the Leg 129 basalts contradicts results of previous studies, which have shown that heavy rare earth elements are not affected by seawater alteration (Frey et al., 1974; Ludden and Thompson, 1979). The trends displayed by these elements may reflect dilution by secondary clay minerals that do not accommodate the heavy rare earth elements to any marked degree.

The effects that late-stage calcite formation has on the basalt physical properties are not readily apparent for the samples analyzed in this study. Calcite replacement is locally extensive, as evidenced by the uppermost sample from Unit 9 of Hole 801C; however, the relationship between velocity and the concentrations of $\mathrm{CaCO}_{3}$ and $\mathrm{CO}_{2}$ is ambiguous. The absence of a relationship in the laboratory samples may be a product of the masking influence of the clay alteration phases on the physical properties. It is also likely that the effects of progressive calcification, such as a positive correlation between velocity and calcite content as a consequence of fracture infilling, are better reflected in the physical properties on a formation scale.

A distinctive aspect of the properties of the Jurassic crust sampled at Site 801 is the low porosity and high bulk density, compressional wave velocity, and thermal conductivity of the basalts of the lower part of the tholeiitic sequence. It has been proposed that as oceanic crust ages, progressive alteration infilling results in a systematic increase in seismic velocity with age (Houtz and Ewing, 1976; Hyndman and Drury, 1976; Spudich and Orcutt, 1980; Carlson and Herrick, 1990). This hypothesis is based primarily on seismic refraction and logging data and characterizes the crustal properties on a formation scale. The extent to which it is applicable to the laboratory data for the Leg 129 basalts is questionable. The Leg 129 basalts that contain the greatest abundance of alteration phases are generally characterized by low compressional wave velocities. The tholeiitic basalts at 
Table 3. Results of chemical analyses of Units 9 and 24 in Hole 801C.

\begin{tabular}{|c|c|c|c|c|c|c|c|c|}
\hline \multirow{2}{*}{$\begin{array}{l}\text { Sample 129-801C. } \\
\text { Unit } \\
\text { Depth (mbsf) } \\
\text { Relative condition }\end{array}$} & \multirow{2}{*}{$\begin{array}{c}5 \mathrm{R}-3,38-43 \mathrm{~cm} \\
9 \\
534.15 \\
\text { Fresh }\end{array}$} & \multirow{2}{*}{$\begin{array}{c}\text { SR-3, } 43-45 \mathrm{~cm} \\
9 \\
534.20 \\
\text { Fresh }\end{array}$} & \multirow{2}{*}{$\begin{array}{c}5 \mathrm{R}-2,87-89 \mathrm{~cm} \\
9 \\
533.33 \\
\text { Moderately altered }\end{array}$} & \multirow{2}{*}{$\begin{array}{c}5 R-1,103-105 \mathrm{~cm} \\
9 \\
532.23 \\
\text { Highly altered }\end{array}$} & \multirow{2}{*}{$\begin{array}{c}8 \mathrm{R}-2,78-80 \mathrm{~cm} \\
24 \\
561.35 \\
\text { Fresh }\end{array}$} & \multirow{2}{*}{$\begin{array}{c}8 \mathrm{R}-1,65-67 \mathrm{~cm} \\
24 \\
560.15 \\
\text { Highly altered }\end{array}$} & \multicolumn{2}{|c|}{$\begin{array}{l}\text { Alteration trends on } \\
\text { mass/volume basis }\end{array}$} \\
\hline & & & & & & & Unit 9 & Unit 24 \\
\hline $\mathrm{SiO}_{2}$ & 45.91 & 46.99 & 45.35 & 52.13 & 47.49 & 46.66 & ns- & - \\
\hline $\mathrm{TiO}_{2}$ & 1.15 & 1.14 & 1.20 & 1.23 & 1.89 & 2.19 & \pm & \pm \\
\hline $\mathrm{Al}_{2} \mathrm{O}_{3}$ & 19.39 & 19.67 & 19.62 & 18.78 & 13.36 & 15.92 & - & \pm \\
\hline $\mathrm{Fe}_{2} \mathrm{O}_{3}$ & 3.46 & 2.74 & 3.85 & 4.76 & 3.48 & 7.86 & + & + \\
\hline $\mathrm{FeO}$ & 3.60 & 4.38 & 1.96 & 0.61 & 8.25 & 2.25 & - & - \\
\hline $\mathrm{MnO}$ & 0.13 & 0.14 & 0.10 & 0.07 & 0.21 & 0.08 & - & - \\
\hline $\mathrm{MgO}$ & 4.79 & 4.92 & 3.06 & 1.86 & 7.40 & 2.99 & - & - \\
\hline $\mathrm{CaO}$ & 13.14 & 13.08 & 13.57 & 5.02 & 12.82 & 10.65 & ns- & - \\
\hline $\mathrm{Na}_{2} \mathrm{O}$ & 2.74 & 2.75 & 2.93 & 1.37 & 2.71 & 3.47 & ns- & \pm \\
\hline $\mathrm{K}_{2} \mathrm{O}$ & 0.06 & 0.08 & 0.70 & 6.88 & 0.08 & 0.84 & + & + \\
\hline $\mathrm{P}_{2} \mathrm{O}_{5}$ & 0.07 & 0.01 & 0.02 & 0.02 & 0.16 & 0.14 & \pm & \pm \\
\hline LOI & 5.06 & 4.22 & 7.27 & 6.74 & 3.34 & 7.30 & nst & + \\
\hline Total & 99.5 & 100.1 & 99.64 & 99.66 & 100.19 & 100.35 & & \\
\hline $\mathrm{H}_{2} \mathrm{O}+$ & 1.44 & 1.50 & 2.36 & 5.77 & 1.45 & 5.34 & + & + \\
\hline $\mathrm{CO}_{2}$ & 3.12 & 3.08 & 5.10 & 1.02 & 2.77 & 2.10 & ns- & - \\
\hline $\mathrm{CaCO}_{3}$ & & 7.2 & 13.3 & 7.2 & 6.7 & 11.9 & \pm & + \\
\hline $\mathrm{Fe}^{3+} / \mathrm{Fe}_{\mathrm{T}}$ & 0.49 & 0.38 & 0.66 & 0.89 & 0.30 & 0.78 & + & + \\
\hline $\mathrm{Ba}$ & 15 & 8 & 14 & 149 & 13 & 29 & + & + \\
\hline $\mathrm{Cr}$ & 335 & 347 & 342 & 341 & 143 & 181 & \pm & \pm \\
\hline $\mathrm{Cu}$ & 86 & 87 & 88 & 20 & 74 & 73 & ns- & - \\
\hline $\mathrm{Nb}$ & 3 & 3 & 2 & 2 & 5 & 4 & \pm & \pm \\
\hline $\mathrm{Ni}$ & 89 & 103 & 85 & 46 & 58 & 61 & ns- & - \\
\hline $\mathrm{Rb}$ & 3 & 3 & 18 & 59 & 2 & 20 & + & + \\
\hline $\mathrm{S}$ & 493 & 467 & 326 & 125 & 541 & 269 & - & - \\
\hline $\mathrm{Sr}$ & 143 & 146 & 155 & 82 & 124 & 150 & ns- & \pm \\
\hline V & 233 & 247 & 245 & 183 & 388 & 528 & ns- & \pm \\
\hline $\mathrm{Y}$ & 24 & 23 & 21 & 25 & 41 & 42 & \pm & \pm \\
\hline $\mathrm{Zn}$ & 56 & 57 & 48 & 39 & 101 & 70 & - & - \\
\hline $\mathrm{Zr}$ & 69 & 69 & 66 & 70 & 112 & 113 & \pm & \pm \\
\hline Cs & 0.12 & & 0.19 & 0.46 & 0.3 & 0.31 & + & \pm \\
\hline Hf & 1.67 & & 1.78 & 1.72 & 3.01 & 3.30 & \pm & \pm \\
\hline $\mathrm{Ta}$ & 0.07 & & 0.06 & 0.05 & 0.19 & 0.193 & \pm & \pm \\
\hline $\mathrm{U}$ & 0.19 & & 0.20 & 0.47 & 0.20 & 0.70 & nst & + \\
\hline $\mathrm{La}$ & 1.37 & & 1.45 & 1.86 & 3.34 & 4.04 & \pm & \pm \\
\hline $\mathrm{Ce}$ & 5.3 & & 5.4 & 6.0 & 10.7 & 12.8 & \pm & \pm \\
\hline $\mathrm{Tb}$ & 0.61 & & 0.51 & 0.57 & 1.04 & 1.00 & \pm & $\mathrm{x}$ \\
\hline $\mathrm{Yb}$ & 2.11 & & 1.93 & 1.78 & 4.04 & 3.45 & - & - \\
\hline $\mathrm{Lu}$ & 0.322 & & 0.267 & 0.247 & 0.605 & 0.511 & - & - \\
\hline
\end{tabular}

Note: Major elements, $\mathrm{LOI}, \mathrm{H}_{2} \mathrm{O}+, \mathrm{CO}_{2}$, and $\mathrm{CaCO}_{3}$ are in weight percent (wt $\%$ ); trace and rare earth elements are in parts per million (ppm).

'Trends with increasing alteration reflecting changes on a mass/volume basis, as in Figures 10,11 and $12:+=$ increase in concentration, $-=$ decrease in concentration, $\pm=$ little change in concentration, $\mathrm{ns}+=$ nonsystematic increase, ns- = nonsystematic decrease.

Site 801 that display the highest velocities are characterized by only slight alteration. As a measure of the relative freshness of these rocks, in terms of their oxygen isotopic composition and petrographic character, the extent of alteration of the Site 801 tholeiites is comparable to that of 10-Ma crust (Alt et al., this volume; Floyd et al., this volume). As a consequence the somewhat high velocities of these rocks, as measured in the laboratory, may not be an end result of progressive alteration associated with aging, but instead the relative freshness of the basalts.

The origin of the correlations between the physical properties of the basalts and the chemical trends that accompany progressive alteration of the rocks can be interpreted in several ways. The extent of alteration can be viewed as being dictated by the variation in the physical properties of the rocks. For example, increased porosity (lower velocity) may be associated with increased fracture abundance or size and accompanying increases in permeability, water content, and alteration. A second possibility is that as alteration proceeds, the physical properties of the rocks change in response to the changing rock composition. The replacement of solid mineral phases with hydrous clay minerals will be accompanied by an increase in water content and porosity, as typified by the samples from Unit 9 in $801 \mathrm{C}$. These two lines of reasoning are both valid, and most likely the correlations between physical properties and chemical trends result from a combination of the processes. The extent to which alteration influences the physical properties is also likely to vary with the scale of the measurements, with differences existing between the laboratory sample scale and larger scales. For the Leg 129 basalts, the observed petrographic changes, the chemical trends consistent with these changes, and the correlation between the chemical trends and physical properties implies that, on the laboratory sample scale, progressive alteration exerts a strong influence on the properties of the basalts.

In summary, the physical properties of basalts from the Pigafetta and East Mariana basins, drilled during Leg 129, vary over a wide range, a variation in which wet-bulk density, compressional wave velocity, and thermal conductivity are strongly correlated with porosity. Comparison of the physical properties with results of major and trace elemental analyses and petrographic examination indicates that variation in the properties on a laboratory sample scale is controlled largely by the extent of alteration of the basalts.

\section{ACKNOWLEDGMENTS}

We thank Richard L. Carlson and one anonymous reviewer for their helpful reviews. This work was partially supported by USSAC grants 20425 (WHB) and 20511 (PRC). 


\section{REFERENCES}

Anderson, R. N., Honnorez, J., Becker, K., et al., 1985. Init. Repts. DSDP, 83: Washington (U.S. Govt. Printing Office)

Boyce, R. E., 1976. Definitions and laboratory determination of compressional sound velocity parameters and wet-water content, wet-bulk density and porosity parameters by gravimetric and gamma-ray attenuation techniques. In Schlanger, S. O., Jackson, E. D., et al., Init. Repts. DSDP, 33: Washington (U.S. Govt. Printing Office), 931-958.

Broglia, C., and Moos, D., 1988. In-situ structure and properties of 110-Ma crust from geophysical logs in DSDP Hole 418A. In Salisbury, M. H., Scott, J. H., et al.,Proc. ODP, Sci. Results, 102: College Station, TX (Ocean Drilling Program).

Cann, J. R., 1969. Spilites from the Carlsberg Ridge, Indian Ocean. J. Petrol., $10: 1-19$.

, 1971. Petrology of basement rocks from Palmer Ridge, N.E. Atlantic. Philos. Trans. R. Soc. London A, 268:605-617.

Cann, J. R., Langseth, M. G., Honnorez, J., Von Herzen, R. P., White, S. M., et al., 1983. Init. Repts. DSDP, 69: Washington (U.S. Govt. Printing Office).

Carlson, R. L., and Christensen, N. L., 1979. Velocity anisotropy in semi-indurated calcareous deep-sea sediments. J. Geophys. Res., 84:205-211.

Carlson, R. L., and Herrick, C. N., 1990. Densities and porosities in the oceanic crust and their variations with depth and age. J. Geophys. Res., 95:9153-9170.

Christensen, N. I., 1973. Compressional and shear wave velocities in basaltic rocks. In van Andel, T. H., Heath, G. R., et al., Init. Repts. DSDP, 16: Washington (U.S. Govt. Printing Office), 647-649.

, 1976. Seismic velocities, densities, and elastic constants of basalts from DSDP, Leg 35. In Hollister, C. D., and Craddock, C., et al., Init. Repts. DSDP, 35: Washington (U.S. Govt. Printing Office), 335-337.

Christensen, N. I., and Salisbury, M. H., 1975. Structure and constitution of the lower crust. Rev. Geophys. Space Phys., 13:57-86.

Christensen, N. I., Wilkens, R. H., Lundquist, S. M., and Schultz, J. P., 1981. Seismic properties of volcanic rocks from Hess Rise. In Thiede, J., Vallier, T. L., et al., Init. Repts. DSDP, 62: Washington (U.S. Govt. Printing Office), 1005-1007.

Curray, J. R., Moore, D. G., et al., 1982. Init. Repts. DSDP, 64: Washington (U.S. Govt. Printing Office).

Duennebier, F. K., Stephen, R., Gettrust, J. F., et al., 1987. Init. Repts. DSDP, 91: Washington (U.S. Govt. Printing Office).

Edmond, J. M., Measures, C., McDuff, R. E., Chan, L. H., Collier, R., Grant, B., Gordon, L. I., and Corliss, J. B., 1979. Ridge crest hydrothermal activity and the balances of the major and minor elements in the ocean: the Galapagos data. Earth Planet. Sci. Lett., 46:1-18.

Frey, F. A., Bryan, W. B., and Thompson, G., 1974. Atlantic Ocean floor: geochemistry and petrology of basalts from Legs 2 and 3 of the Deep Sea Drilling Project. J. Geophys. Res., 79:5507-5527.

Hamano, Y., 1979. Physical properties of basalts from Holes 417D and 418A. In Donnelly, T., Francheteau, J., Bryan, W., Robinson, P., Flower, M., Salisbury, M., et al., Init. Repts. DSDP, 51, 52, 53: Washington (U.S. Govt. Printing Office), 1457-1466.

Hamilton, E. L., 1971. Prediction of in-situ acoustic and elastic properties of marine sediments. Geophysics, 36:266-284.

Hart, R. A., 1970. Chemical exchange between sea water and deep ocean basalts. Earth Planet. Sci. Lett., 9:269-279.

, 1973. A model for chemical exchange in the basalt-seawater system of oceanic layer II. Can. J. Earth Sci., 10:799-816.

Hart, S. R., Erlank, A. J., and Kable, E.J.D., 1974. Sea floor basalt alteration: some chemical and Sr isotopic effects. Contrib. Mineral. Petrol., 44:219-230.

Honnorez, J., Von Herzen, R. P., et al., 1983. Init. Repts. DSDP, 70: Washington (U.S. Govt. Printing Office).

Houtz, R., and Ewing, J., 1976. Upper crustal structure as a function of plate age. J. Geophys. Res., 81:2490-2498.
Humphris, S. E., and Thompson, G., 1978. Hydrothermal alteration of oceanic basalts by seawater. Geochim. Cosmochim. Acta, 42:107-125.

Hyndman, R. D., Christensen, N. I., and Drury, M. J., 1979. Seismic velocities, densities, electrical resistivities, porosities and thermal conductivities of core samples from boreholes into the islands of Bermuda and the Azores. In Talwani, M., Harrison, C. G., and Hayes, D. E. (Eds.), Deep Drilling Results in the Atlantic Ocean: Ocean Crust. Am. Geophys. Union, Geophys. Monogr., Maurice Ewing Ser., 2:94-112.

- 1984. The physical properties of basalt core samples from Deep Sea Drilling Project Leg 78B Hole 395A. In Hyndman, R. D., Salisbury, M. H., et al., Init. Repts. DSDP, 78 (Pt. 2): Washington (U.S. Govt. Printing Office), 801-810.

Hyndman, R. D., and Drury, M. J., 1976. The physical properties of oceanic basement rocks from deep drilling on the Mid-Atlantic Ridge. J. Geophys. Res., 81:4042-4060.

Jackson, E. D., Koizumi, I., et al., 1980. Init. Repts. DSDP, 55: Washington (U.S. Govt. Printing Office).

Kerr, P. F., 1977. Optical Mineralogy: New York (McGraw-Hill).

Kono, M., Hamano, Y., and Morgan, W. J., 1980. Physical properties of basalts from DSDP Leg 55. In Jackson, E. D., Koizumi, I., et al., Init. Repts. DSDP, 55: Washington (U.S. Govt. Printing Office), 715-721.

Lancelot, Y., Larson, R. L., et al. 1990. Proc. ODP, Init. Repts., 129: College Station, TX (Ocean Drilling Program).

Larson, R. S., Schlanger, S. O., et al., 1981. Init. Repts. DSDP, 61: Washington (U.S. Govt. Printing Office).

Leinen, M., Rea, D. K., et al., 1986. Init. Repts. DSDP, 92: Washington (U.S. Govt. Printing Office).

Lewis, B.T.R., Robinson, P., et al., 1983. Init. Repts. DSDP, 65: Washington (U.S. Govt. Printing Office).

Ludden, J. N., and Thompson, G., 1979. An evaluation of the behaviour of rare earth elements during weathering of sea-floor basalt. Earth Planet. Sci. Lett., 43:85-92.

Moberly, R., Schlanger, S. O., et al., 1986. Init. Repts. DSDP, 89: Washington (U.S. Govt. Printing Office).

Newmark, R., and Moos, D., 1986. Physical properties of basalt samples from Deep Sea Drilling Project Site 597. In Leinen, M., Rea, D. K., et al., Init. Repts. DSDP, 92: Washington (U.S. Govt. Printing Office), 537-543.

Oxburgh, E. R., and Agrell, S. O., 1982. Thermal conductivity and temperature structure of the Reydarfjordur Borehole. J. Geophys. Res., 87:6423-6428.

Paster, T. P., 1968. Petrologic variations within submarine basalt pillows of the South Pacific-Antarctic Ocean [Ph.D. dissert.]. Florida State Univ., Tallahassee.

Ratcliffe, E. H., 1960. The thermal conductivities of ocean sediments. J. Geophys. Res., 65:1535-1541.

Robertson, E. C., and Peck D. L., 1974. Thermal conductivity of vesicular basalt from Hawaii. J. Geophys. Res., 79:4875-4888.

Rosendahl, B. R., Hekinian, R., et al., 1980. Init. Repts. DSDP, 54: Washington (U.S. Govt. Printing Office).

Salisbury, M. H., and Christensen, N. I., 1976. Sonic velocities and densities of basalts from the Nazca Plate, DSDP Leg 34. In Yeats, R. S., Hart, S. R., et al., Init. Repts. DSDP, 34: Washington (U.S. Govt. Printing Office), 543-546.

Spudich, P., and Orcutt, J., 1980. A new look at the seismic velocity structure of the oceanic crust. Rev. Geophys. Space Phys., 18:627-645.

Staudigel, H., Hart, S. R., and Richardson, S. H., 1981. Alteration of the oceanic crust: processes and timing. Earth Planet. Sci. Lett., 52:311-327.

Vacquier, V., 1985. The measurement of thermal conductivity of solids with a transient linear heat source on the plane surface of a poorly conducting body. Earth Planet. Sci. Lett., 74:275-279.

Date of initial receipt: 5 June 1991

Date of acceptance: 13 January 1992

Ms 129B-139 

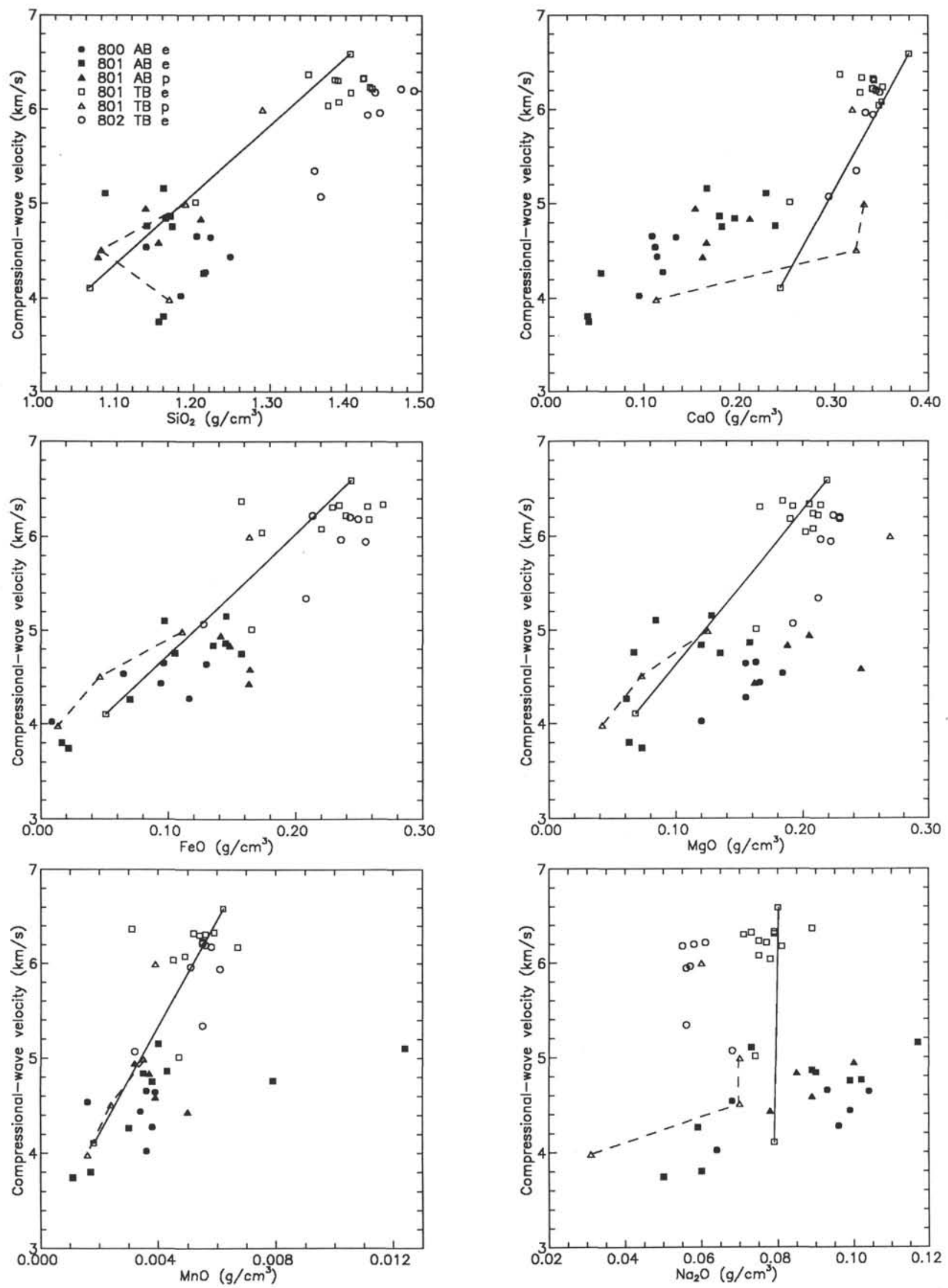

Figure 10. Compressional wave velocity as a function of major element chemistry for the Leg 129 basalts. The three samples from Unit 9 and two samples from Unit 24 of Hole $801 \mathrm{C}$ are connected by dashed and solid lines, respectively. 

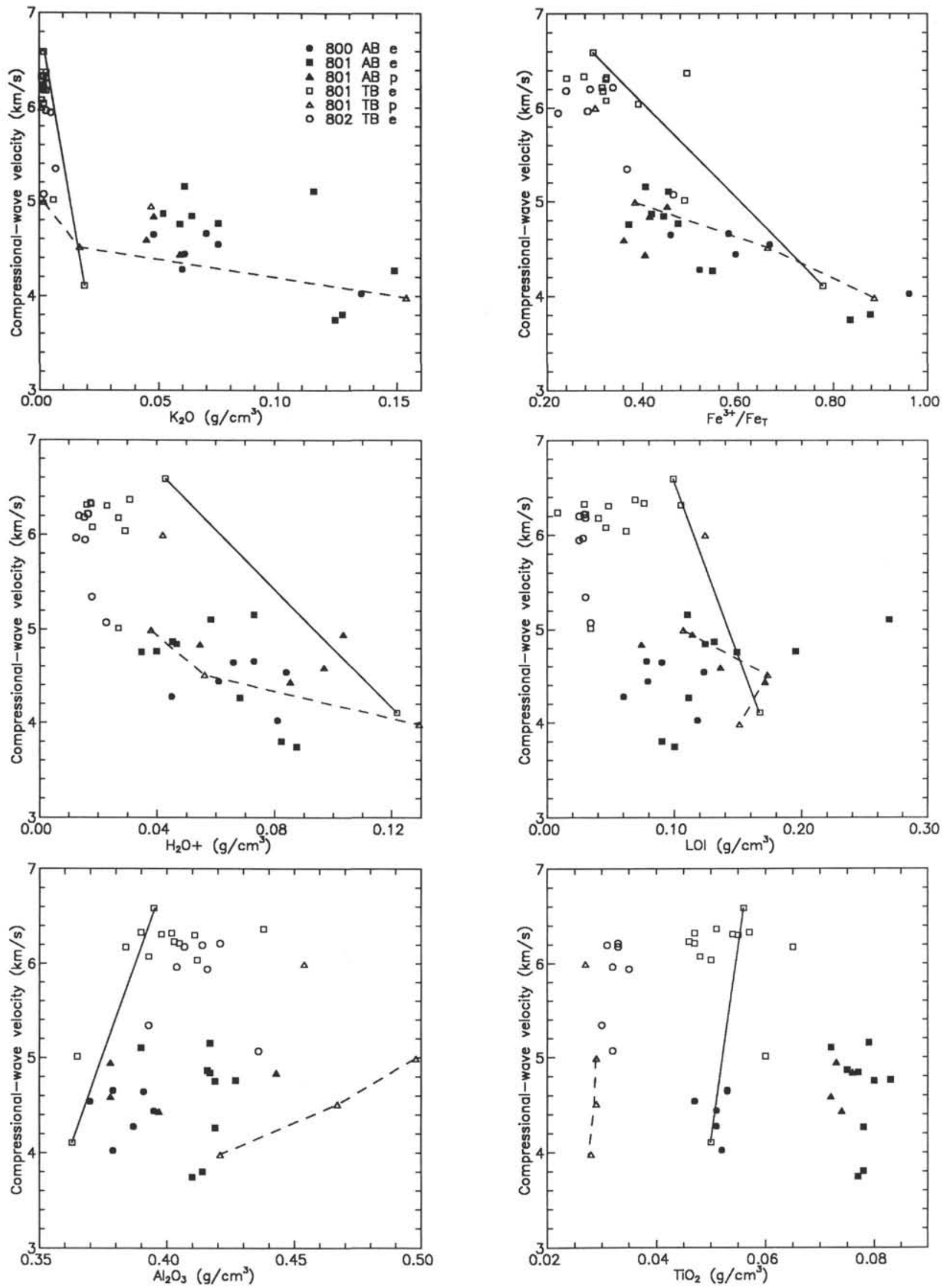

Figure 10 (continued). 
W. H. BUSCH, P. R. CASTILLO, P. A. FLOYD, G. CAMERON
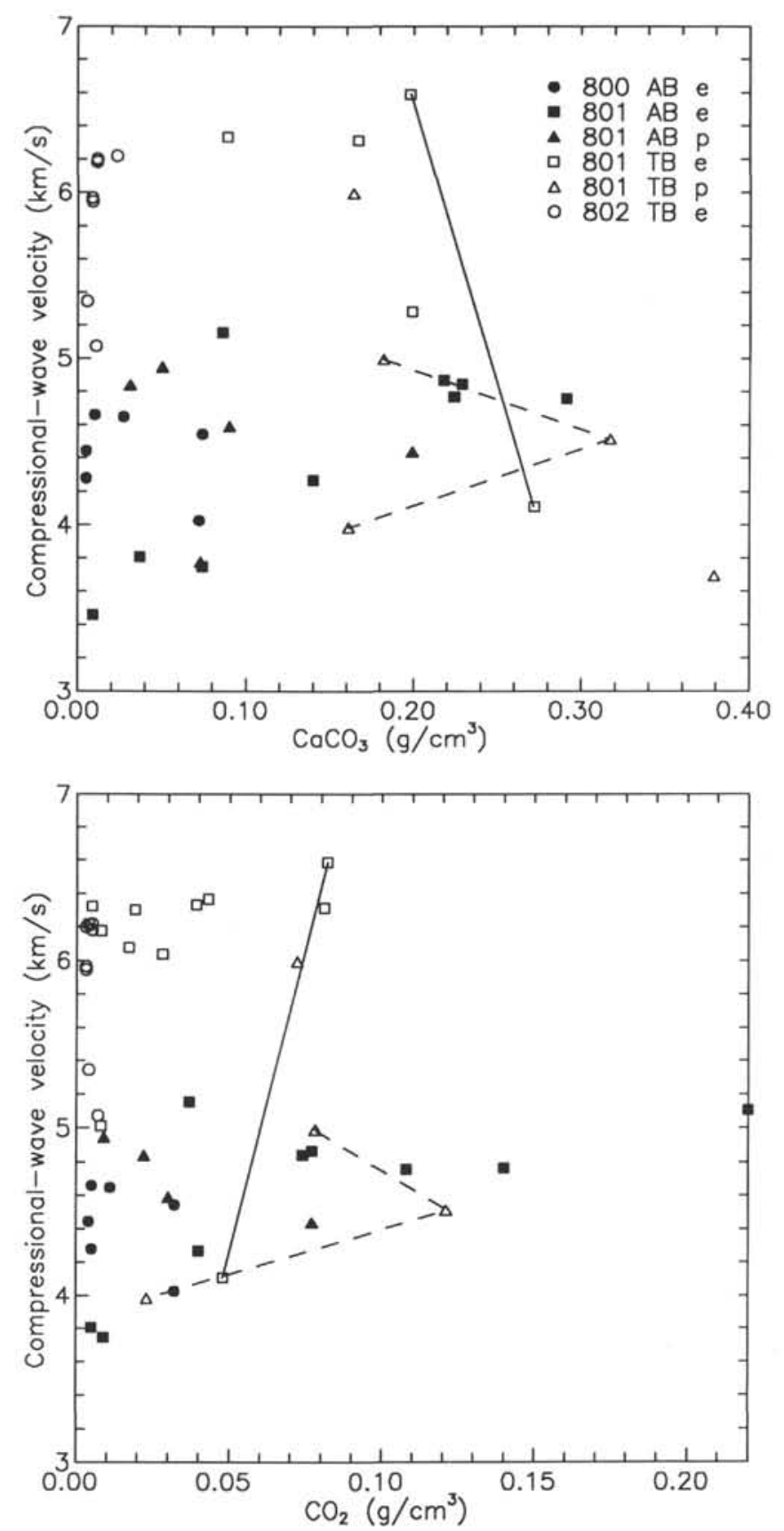

Figure 11. Compressional wave velocity as a function of $\mathrm{CaCO}_{3}$ and $\mathrm{CO}_{2}$ contents for the Leg 129 basalts. The three samples from Unit 9 and two samples from Unit 24 of Hole $801 \mathrm{C}$ are connected by dashed and solid lines, respectively. 

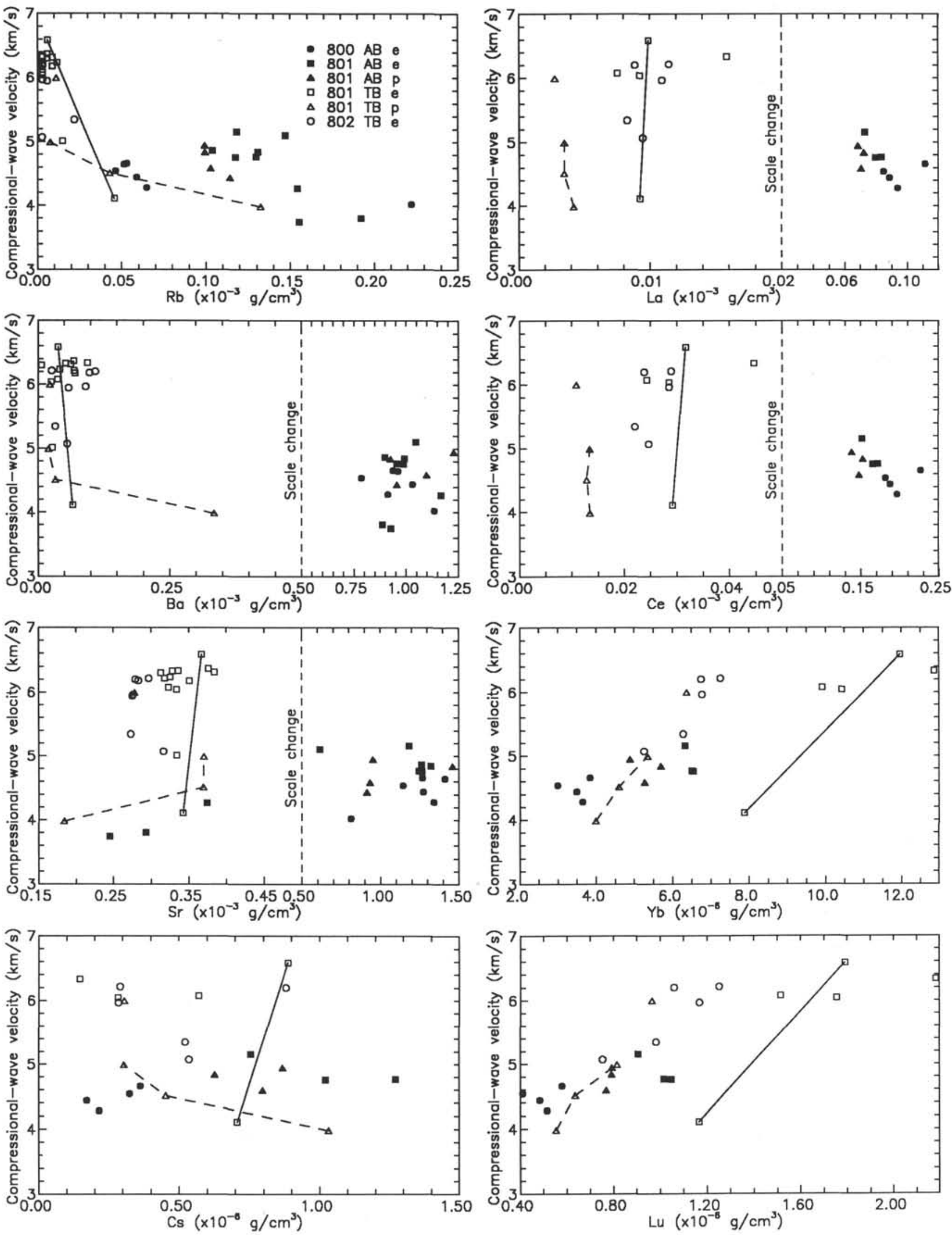

Figure 12. Compressional wave velocity as a function of selected trace element chemistry for the Leg 129 basalts. The three samples from Unit 9 and two samples from Unit 24 of Hole $801 \mathrm{C}$ are connected by dashed and solid lines, respectively. 